No $2008-05$

April

On the Influence of Oil Prices on Economic Activity and Other Macroeconomic and Financial Variables

François Lescaroux

Valérie Mignon 
On the influence of oil prices on economic activity and other macroeconomic and financial variables

François Lescaroux

Valérie Mignon

No $2008-05$

April 


\section{CONTENT}

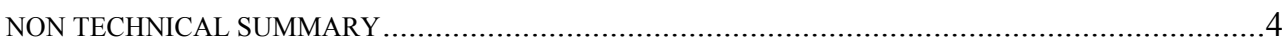

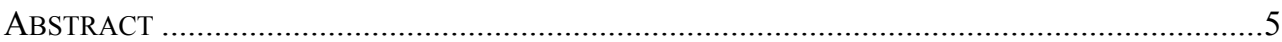

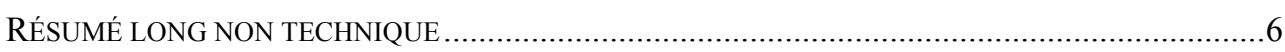

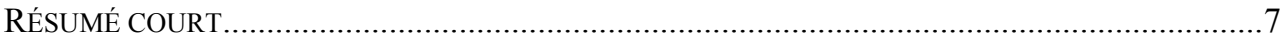

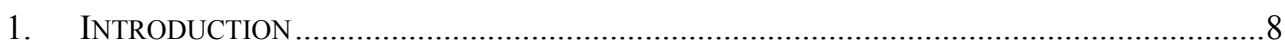

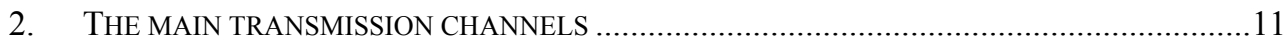

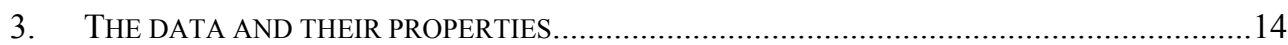

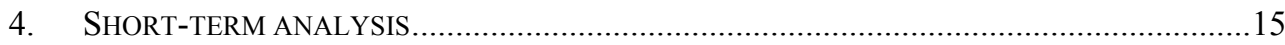

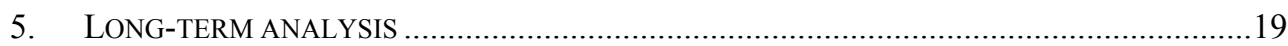

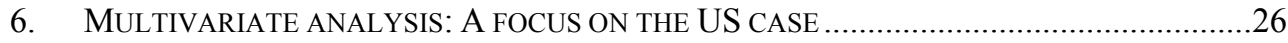

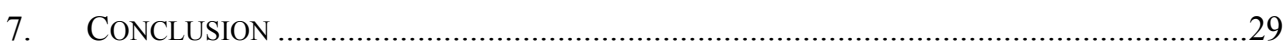

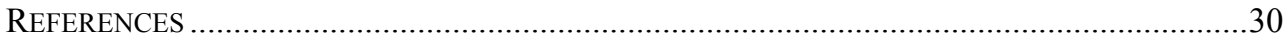




\section{ON THE INFLUENCE OF OIL PRICES ON ECONOMIC ACTIVITY AND OTHER} MACROECONOMIC AND FINANCIAL VARIABLES

\section{NON TECHNICAL SUMMARY}

Various transmission channels exist through which oil prices may have an impact on economic activity. In this paper, our aim is to investigate the links between oil prices and various macroeconomic and financial variables for three groups of countries: OPEC, oilexporting countries and oil-importing countries. We consider the following variables, representative of economic activity: gross domestic product (GDP), consumer price index (CPI), household consumption, unemployment rate and share prices.

Most of the previous studies focus on short term interactions between oil prices and economic activity in the US and consider mainly output, inflation and unemployment. Since the seminal works of Hamilton (1983) and Burbidge and Harrison (1984), a causal relationship has been identified between oil price changes and variations in macroeconomic indicators such as GNP and the unemployment rate in the US, with causality running from the former to the latters.

As to the other countries, far fewer studies have been produced. Mork et al. (1994) and Jimenez-Rodriguez and Sanchez (2005) confirmed that the results obtained for the US were valid for Japan, Germany, France, Canada, the United Kingdom and Norway. As to Papapetrou (2001), she analyzed the impact of the consumer price index of petroleum products on the Greek economy and obtained causal relationships from oil prices to industrial production, employment and share prices.

Considering the long term interactions between oil prices and economic activity, very few studies have been realized. Rasche and Tatom (1977b, 1981) have estimated Cobb-Douglas production functions to evaluate the impact of energy prices on potential output for Canada, France, Germany, Japan, the UK and the US. Other authors like Carruth, Hooker and Oswald (1998) and Hooker (2002) have estimated a long-term (cointegrating) relationship between unemployment, real interest rate and real oil prices. More recently, Lardic and Mignon (2006) have shown that asymmetric cointegration can be found between oil prices and GDP in the US and European countries.

In this paper, both short-run and long-run interactions between oil prices and the various macroeconomic and financial variables are analyzed. Concerning the short run, we implement causality tests and evaluate cross-correlations between the cyclical components of the series in order to identify lead/lag relationships. Turning to the long run, cointegration analysis is used, both in a time series and in a panel framework. Considering a panel data context allows to highlight common behaviors for groups of countries. Finally, focusing on the US case, a multivariate model is estimated to put forward the mechanisms of propagation of an oil price change through the economy.

Concerning the short term analysis, our results indicate that when causality exists, it generally runs from oil prices to the other considered variables. One of the most interesting results is relating to stock markets since we show that there exists a strong causality 
running from oil to share prices, especially for oil-exporting countries. This result is confirmed by the calculation of cyclical correlations where oil prices are found to lead countercyclically share prices for almost every country: an oil price increase leads to a reduction of profits of non-oil exporting firms leading to a decrease in share prices. Turning to the long term analysis, the majority of long-run relationships concerns GDP, unemployment rate and share prices. Indeed, GDP and oil prices countercyclically in the long run for twelve countries. The relationships relating to unemployment rates and share prices only concern non-OPEC members. Concerning share prices, the causality is negative and always runs from oil prices to stock markets, putting forward the key role played by the oil market.

\begin{abstract}
The aim of this paper is to investigate the links between oil prices and various macroeconomic and financial variables for a large set of countries, including both oilimporting and exporting countries. Both short-run and long-run interactions are analyzed through the implementation of causality tests, evaluation of cross-correlations between the cyclical components of the series in order to identify lead/lag relationships and cointegration analysis. Our results highlight the existence of various relationships between oil prices and macroeconomic variables and, especially, an important link between oil and share prices on the short run. Turning to the long run, numerous long-term relationships are detected, the causality generally running from oil prices to the other variables. An important conclusion is relating to the key role played by the oil market on stock markets.
\end{abstract}

JEL Classification: C22; C23 ; Q43.

Keywords: oil prices, economic activity, causality, cyclical correlations, cointegration, VAR processes. 


\section{L'INFLUENCE DES PRIX DU PETROLE SUR L'ACTIVITE ECONOMIQUE ET SUR LES AUTRES VARIABLES MACROECONOMIQUES ET FINANCIERES}

\section{RESUME LONG NON TECHNIQUE}

Il existe de nombreux canaux de transmission par lesquels les prix du pétrole peuvent exercer une influence sur l'activité économique. Dans cet article, notre objet est d'étudier les liens entre les prix du pétrole et diverses variables macroéconomiques et financières pour trois groupes de pays : les pays membres de l'OPEP, les pays exportateurs et les pays importateurs de pétrole. Nous considérons un ensemble de variables représentatives de l'activité économique au sens large: le produit intérieur brut, l'indice des prix à la consommation, la consommation des ménages, le taux de chômage et les cours boursiers.

La plupart des études existant sur le sujet s'intéresse aux interactions de court terme entre les prix du pétrole et l'activité économique aux Etats-Unis et porte essentiellement sur le PIB, l'inflation et le taux de chômage. Depuis les travaux pionniers de Hamilton (1983) et Burbidge et Harrison (1984), il est admis qu'il existe une relation de causalité des prix du pétrole vers certaines variables macroéconomiques, comme le PIB ou le taux de chômage aux Etats-Unis.

Très peu d'études ont été réalisées concernant les autres pays que les Etats-Unis. Les travaux de Mork et al. (1994) et Jimenez-Rodriguez et Sanchez (2005) constituent cependant une exception et montrent que les résultats obtenus pour les Etats-Unis sont valides dans le cas du Japon, de l'Allemagne, de la France, du Canada, du Royaume Uni et de la Norvège. L'étude de Papapetrou (2001), analysant l'impact de l'indice des prix à la consommation des produits pétroliers sur l'économie en Grèce, met également en évidence l'existence de relations de causalité des prix du pétrole vers la production industrielle, l'emploi et les cours boursiers.

Concernant à présent les interactions de long terme entre les prix du pétrole et l'activité économique, très peu de travaux ont été menés. Rasche et Tatom (1977b, 1981) ont procédé à l'estimation de fonctions de production de type Cobb-Douglas afin d'évaluer l'impact des prix de l'énergie sur le PIB potentiel pour le Canada, la France, l'Allemagne, le Japon, le Royaume Uni et les Etats-Unis. D'autres auteurs, comme Carruth, Hooker et Oswald (1998) et Hooker (2002) ont estimé une relation de long terme (relation de cointégration) entre le taux de chômage, le taux d'intérêt réel et les prix réels du pétrole. Plus récemment, Lardic et Mignon (2006) ont mis en évidence l'existence d'une relation de cointégration asymétrique entre les prix du pétrole et le PIB pour les Etats-Unis et différents pays européens.

Dans cet article, les interactions entre le prix du pétrole et les différentes variables macroéconomiques et financières sont analysées tant à court terme qu'à long terme. Concernant le court terme, sont mis en œuvre des tests de causalité et des calculs de corrélations croisées entre les composantes cycliques des séries afin d'identifier l'existence de relations avancées, retardées ou coïncidentes entre les variables. S'agissant du long terme, nous procédons à une étude de cointégration en séries temporelles et en panel ; 
l'approche en termes de données de panel permettant de mettre en avant l'existence de comportements communs à plusieurs groupes de pays. Enfin, pour les Etats-Unis, un modèle multivarié est estimé afin de rendre compte des mécanismes de propagation d'une variation du prix du brut sur l'économie.

En ce qui concerne l'analyse de court terme, nos résultats montrent que lorsqu'une causalité existe, celle-ci s'exerce généralement des prix du pétrole vers les autres variables. Un résultat particulièrement intéressant concerne les marchés financiers pour lesquels nous montrons qu'il existe une forte causalité des prix du pétrole vers les cours boursiers, surtout pour les pays exportateurs de pétrole. Ce résultat est confirmé par le calcul des corrélations cycliques d'où il ressort que les prix du pétrole constituent un indicateur avancé contracyclique des cours boursiers pour la plupart des pays : une hausse des prix du brut engendre une baisse des profits des entreprises des pays non exportateurs, conduisant à une baisse des cours boursiers. Concernant à présent l'analyse de long terme, la majorité des relations de cointégration mises en avant concerne le PIB, le taux de chômage et les cours boursiers. Ainsi, il apparaît que le PIB et les prix du pétrole évoluent ensemble de façon contracyclique à long terme pour douze pays. Les relations de long terme relatives au taux de chômage et aux cours boursiers concernent les pays non membres de l'OPEP. Enfin, s'agissant plus précisément des cours boursiers, la causalité est négative et s'exerce toujours des prix du pétrole vers les marchés boursiers, mettant ainsi en avant le rôle central joué par le marché pétrolier.

\section{RESUME COURT}

Ce papier a pour objet d'étudier les liens entre le prix du pétrole et diverses variables macroéconomiques et financières pour un large ensemble de pays, incluant à la fois des pays importateurs et exportateurs de pétrole. Tant les interactions de court terme que celles de long terme sont analysées. A cette fin sont mis en œuvre des tests de causalité, des calculs de corrélations croisées entre les composantes cycliques des séries afin d'identifier l'existence de relations avancées, retardées ou coïncidentes entre les séries et des tests de cointégration. A court terme, nos résultats font ressortir l'existence de diverses relations entre le prix du pétrole et les variables macroéconomiques et financières. Ils mettent notamment en évidence un lien important entre le prix du brut et les cours boursiers. S'agissant du long terme, un grand nombre de relations sont détectées, la causalité s'exerçant généralement des prix du pétrole vers les autres variables. Un résultat important concerne le rôle central joué par le marché du pétrole sur l'activité boursière.

Classification JEL: C22 ; C23 ; Q43.

Mots clés : $\quad$ prix du pétrole, activité économique, causalité, corrélations cycliques, cointégration, processus VAR. 


\title{
ON THE INFLUENCE OF OIL PRICES ON ECONOMIC ACTIVITY AND OTHER MACROECONOMIC AND FINANCIAL VARIABLES
}

\author{
François Lescaroux ${ }^{*}$ Valérie Mignon ${ }^{* *}$
}

\section{INTRODUCTION}

As noticed by Brown and Yücel (2002), Jones, Leiby and Paik (2004) or Lardic and Mignon (2006) among others, various transmission channels exist through which oil prices may have an impact on economic activity. The rise in the price of crude oil is passed on to the price of petroleum products and, from the consumer standpoint (households, industry and government), the energy bill grows, whereas from the production standpoint, companies have to contend with a rise in unit costs. All in all, a rise in the energy price causes a drop in productivity, which is passed on to (i) real wages and employment; (ii) selling prices and core inflation; (iii) profits and investment, as well as stock market capitalization.

Although numerous, the previous literature focuses on the specific impact of oil price movements on gross domestic product (GDP) and on prices on the US economy. ${ }^{1}$ Here, we extend the scope of the analysis to the various links between oil prices and several macroeconomic and financial variables for three groups of countries: OPEC, oil-exporting countries and oil-importing countries. We consider the following variables: gross domestic product, consumer price index (CPI), household consumption, unemployment rate and share prices.

The link between oil prices and GDP can be understood via the classic supply-side effect according to which rising oil prices are indicative of the reduced availability of a basic input to production, leading to a reduction of potential output (see, among others, Barro, 1984; Brown and Yücel, 1999; Abel and Bernanke, 2001). Consequently, there is an increase in production cost, and the growth of output and productivity are slowed. This link between oil prices and GDP has been widely studied in the literature (see the survey by Brown and Yücel (2002) and Hamilton (2005) for instance). Generally, the studies tend to find that oil price increases have a negative impact on output, while this impact seems to have weakened over time, especially since the late 1990s. One interpretation is that, since the late 1990s, the global economy has experienced two major oil shocks. While being of a sign and magnitude comparable to those of the 1970s, GDP growth and inflation have remained quite stable in the majority of industrialized countries. According to Blanchard and Gali (2007), a plausible explanation is that the effects of an oil price increase are similar across periods, but have coincided in time with large shocks of a very different

\footnotetext{
* Institut français du pétrole, IFP, France. Email: francois.lescaroux@ifp.fr.

** EconomiX-CNRS, University of Paris 10, and CEPII, France. Email: valerie.mignon@cepii.fr.

${ }^{1}$ See the seminal works of Hamilton $(1983,1996)$ and Bruno and Sachs $(1985)$, and the surveys of Brown and Yücel (2002) and Hamilton (2005) among others.
} 
nature: large increases in other commodity prices in the 1970s, and high growth of productivity and world demand for oil in the 2000s. ${ }^{2}$

Turning to CPI, an oil price increase represents an inflationary shock (Fuhrer, 1995; Gordon, 1997; Hooker, 2002) which can be accompanied by second round effects, through the price-wage loop. The reaction of consumer prices and inflation to oil price movements has been investigated by many authors, such as Hooker (2002), Barsky and Kilian (2004) or LeBlanc and Chinn (2004). While Barsky and Kilian (2004) show that oil price increases generate high inflation, LeBlanc and Chinn (2004) argue that oil prices have only a moderate impact on inflation.

An oil price increase may also have a negative effect on consumption, investment and unemployment. Consumption is affected through its positive relation with disposable income, and investment by raising firms' costs and, possibly, by increasing uncertainty, which leads to a postponement of investment decisions (Ferderer, 1996). Finally, if the oil price increase is long-lasting, it can give rise to a change in the production structure and have a deeper impact on unemployment. Indeed, a rise in oil prices diminishes the return of sectors that are oil-intensive and can incite firms to adopt and construct new production methods that are less intensive in oil inputs. This change generates capital and labor reallocations across sectors that can affect unemployment in the long run (Loungani, 1986). In this context, Caruth, Hooker and Oswald (1998) have investigated the impact of oil price movements on the labor market and Davis and Haltiwanger (2001) focused on the influence of oil price dynamics on the natural rate of unemployment. The impact of oil price movements on the labor market can differ according to the considered horizon. As shown by Keane and Prasad (1996), oil price increases tend to reduce employment in the short run but to increase it in the long run. This reverse relationship in the long run may be due to the complementarities and substitutabilities across different segments of the labor market.

Oil price movements may also have an impact on stock prices. While there is a huge literature concerning the links between oil prices and economic activity, the literature relating to the relationship between oil prices and stock markets is rare. There is however a growing interest for this relation, mainly due to the increasing financial integration process. The impact of oil price movements on share prices has notably been investigated by Jones and Kaul (1996), Sadorsky (1999) or El-Sharif et al. (2005). The seminal work by Jones and Kaul (1996) puts forward that oil prices impact the US stock market, through their influence on expected dividends and cash-flows. Using a VAR framework, Sadorsky (1999) also concludes to the existence of an oil price influence on share prices.

As already mentioned, most of the studies performed on the impact of oil prices focus on short term interactions between oil prices and economic activity in the US and consider mainly output, inflation and unemployment. Since the seminal works of Hamilton (1983) and Burbidge and Harrison (1984), a Granger-causal relationship has been identified between oil price changes and variations in macroeconomic indicators such as GNP

\footnotetext{
${ }^{2}$ Concerning the changing impact of oil price shocks, see also Hooker (2002), De Gregorio et al. (2007), Herrera and Pesavento (2007) and Edelstein and Kilian (2007).
} 
(negative correlation) and the unemployment rate (positive correlation) in the US, with causality running from the former to the latters. ${ }^{3}$

As to the other countries, far fewer studies have been produced. Worth mentioning are Mork et al. (1994), Papapetrou (2001) and Jimenez-Rodriguez and Sanchez (2005). Mork et al. and Jimenez-Rodriguez and Sanchez confirmed that the results obtained for the US were valid for Japan, Germany, France, Canada, the United Kingdom and Norway (with a positive effect of oil price changes on output for this last country). As to Papapetrou (2001), she analyzed the impact of the consumer price index of petroleum products on the Greek economy and obtained causal relationships from oil prices to industrial production, employment and share prices.

Considering the long term interactions between oil prices and economic activity, very few studies have been carried out. Rasche and Tatom (1977b, 1981) have estimated CobbDouglas production functions to evaluate the impact of energy prices on potential output for Canada, France, Germany, Japan, the UK and the US. In a VECM framework, Carruth, Hooker and Oswald (1998) and Hooker (2002) have estimated a cointegrating relationship between unemployment, real interest rate and real oil prices. More recently, Lardic and Mignon (2006) have shown that asymmetric cointegration can be found between oil prices and GDP in the US and European countries.

In this paper, our aim is to investigate for a large set of countries (including both importing and exporting countries) the links between oil prices and a set of variables representative of economic activity: gross domestic product, consumer price index, household consumption expenditures, unemployment rate and share prices. Further, we analyze both short-run and long-run interactions. Concerning the short run, we implement causality tests and evaluate cross-correlations between the cyclical components of the series in order to identify lead/lag relationships. Turning to the long run, cointegration analysis is used, both in a time series and in a panel framework. Considering a panel data context allows to highlight common behaviors for groups of countries. To complement these bivariate analyses, we also estimate a multivariate process in order to put forward the mechanisms of propagation of an oil price change on the economy for the US case.

The rest of the paper is organized as follows. Section 2 recalls the main transmission channels through which an oil price increase may affect economic activity. Section 3 describes the data and their properties. Section 4 is devoted to the short-term analysis. We proceed to short-run Granger causality tests, with a special attention paid to the link between oil price and share price movements. We also derive cross-correlations between the cyclical components of the series in order to put forward lead/lag relationships. Section 5 concerns the long-term analysis and proposes to study the links between oil prices and the other variables in a cointegration framework, both in a time series and in a panel context. Section 6 extends the bivariate analysis to the multivariate case, with a special focus on the US economy. Finally, Section 7 concludes.

\footnotetext{
${ }^{3}$ For a detailed presentation, see the series of reviews by Jones and Leiby (1996) and Jones et al. (1997, 2002, 2004).
} 


\section{THE MAIN TRANSMISSION CHANNELS}

Since the mid-1970s, oil price movements have been considered by many economists and econometricians as a major source of business cycle fluctuations. Since then, efforts have been made to analyze the mechanisms whereby oil price shocks affect the macroeconomy and to measure the impact of these shocks on economic growth (see the detailed reviews by Jones and Leiby, 1996; Jones et al., 1997, 2002, 2004; and Brown and Yücel, 2002).

Despite the substantial research on the impacts of oil prices on economic activity, we are still far from a consensus about the transmission channels. Moreover, the way oil prices influence the economy and the magnitudes of their effects may have evolved through time. Indeed, the mechanisms which were at work during the first two shocks are not necessarily the same today, i.e. since the beginning of the 2000s. Let us recall the main usual impacts of oil prices on economic activity, which were observed during the first two shocks, and try to give some explanations about the current situation. Indeed, the 2000s period is characterized by large magnitudes of oil price increases that seem to have a low or tempered impact on the economy of oil-importing countries.

Globally, the 1970s were characterised by an increasing dependence of the economies on oil, large and unprecedented movements in the oil market and poor macroeconomic context, especially in the United States. In this configuration, it was natural to investigate the potential links between oil prices and macroeconomic activity. Initial studies aimed to elucidate the new oil shock phenomenon by exploring its effects from the demand side: a hike in the crude price was taken as an exogenous inflationary shock (Pierce and Enzler, 1974) or as a transfer of wealth from importing to exporting countries, through a shift in the terms of trade (Hickman, Huntington and Sweeney, 1987). This shift, in turn, depends on energy-import intensity. The bigger the intensity, the bigger the macroeconomic impact. By and large, these analyses identified the following consequences: a slowdown in domestic demand (hence lower GDP and higher unemployment) and inflationary pressure (a risk of tighter monetary policy).

An increase in the oil price also affects supply (Rasche and Tatom, 1977a,b,c), because energy is one of the basic inputs in the production process. As a consequence, the rise of the cost of energy can be interpreted as a reduced availability of a basic input to production, leading to an increase in cost of production. This leads to a decline in the output growth and productivity. The Real Business Cycle theory developed in the 1980s reinforced the interpretation whereby oil shocks were supply shocks and most subsequent studies were done within this theoretical framework.

Given these two-side effects, let us provide more details about the transmission channels through which oil prices influence the economy. As previously mentioned, an oil price increase can be viewed as an inflationary shock. As a consequence, an oil price increase leads to a rise in the consumer price index (CPI), depending upon the share of oil products in the consumption basket. In addition to this direct effect, there are also second-round effects. Due to the decline of their purchasing power, households may ask for increasing wages, leading to price-wage loops. Turning to the firms, they can pass the oil price increase on to selling prices. These effects tend to feed a wage-price spiral and to generate 
upward revisions of inflation expectations. These impacts of an oil price increase on inflation were clearly at work during the first two shocks. However, the influence of the 2000's increase seems to be weaker. Three possible explanations can be given. First, the credibility of the central banks' monetary policy in terms of fight against inflation is higher today than in the 1970s. This can be explained by the fact that most central banks have now inflation targets, rather than only output targets, and act more rapidly than in the past in dampening inflationary pressures. Moreover, central banks are now mostly independent, which was not the case during the 1970s. Second, due to the fact that wages are no longer indexed on prices, second-round effects are almost inexistent today. Third, due to the intensification of the international competition, firms cannot pass the oil price increase on to selling prices. On the whole, the impact of an oil price increase is weaker today than during the two previous shocks and the risk of an inflationary spiral is more limited.

An oil price increase may also have a negative impact on consumption, investment and employment. Consumption is affected through its positive relation with disposable income, and investment by increasing firms' costs. Considering households, an oil price increase generates a rise in domestic fuel prices leading to a decrease of their purchasing power and slowing their consumption expenditures. This effect can however be tempered if consumers expect the rise in oil prices to be transitory. In this case, they will attempt to smooth their consumption by saving less or borrowing more, pushing upward real interest rates. Turning to employment, if the oil price increase is long lasting, it may lead to a change in the production structure and have a deeper impact on unemployment. Indeed, as previously mentioned, a rise in oil prices diminishes the return of sectors that are oil-intensive and can incite firms to adopt and construct new production methods that are less intensive in oil inputs. This generates capital and labor reallocations across sectors that may affect unemployment (Loungani, 1986). It should be noted that this impact can be mitigated after some time. Conditioning on the effectiveness of such reallocations, the impact of an oil price increase on unemployment should be insignificant in the long run (Keane and Prasad, 1996).

Oil price movements may also influence stock prices. This link can be understood via the definition of the fundamental value of an asset. This fundamental value is defined as the discounted sum of expected future dividends. As a consequence, an oil price increase tends to reduce profits of non-oil exporting firms, leading to a decline in the fundamental value. We thus expect a negative link between oil prices and share prices. As previously mentioned, the literature relating to the relationship between oil prices and stock markets is rare and the main references are by Jones and Kaul (1996), Sadorsky (1999) and El-Sharif et al. (2005).

On the whole, various transmission channels exist through which oil prices may affect economic activity. This has generated numerous studies, since the seminal paper of Hamilton (1983) who identified a Granger-causal relationship between oil price changes and variations in macroeconomic indicators such as GNP (negative correlation) and the unemployment rate (positive correlation) in the United States. In both cases, the causality ran from oil prices to macroeconomic variables. Burbidge and Harrison (1984) came to the same conclusion but using a slightly different approach. As more data has become available, however, this relationship appears weaker and seems no longer statistically significant at conventional levels. Mork (1989) was the first to propose filtering the oil 
price signal to restore the causal relationship identified by Hamilton. With data running through 1988, he showed that only oil price increases Granger-caused GNP variations, while oil price collapses had no significant impact on economic activity. Possible explanations for this asymmetry rely on monetary policy, adjustment costs, adverse effects of uncertainty on the investment environment (Ferderer, 1996), and asymmetry in petroleum product prices (for a detailed study, see Lardic and Mignon, 2006 and the references therein).

The effects previously described concerning the impact of oil prices on economic activity were clearly at work during the first two shocks, but have been less apparent since the 1990s. For instance, Hooker (1996) shows that, in the 1990s, oil price increases no longer Granger-caused GNP or unemployment variations. Various interpretations are possible. First, oil prices have never been an important source of fluctuations in economic activity and their impact was overstated (Tobin, 1980; Darby, 1982, 1984; Bohi, 1991). Second, oil price shocks affect the macroeconomy directly or indirectly through various channels. As a result, this relationship is more complex that might have been expected, considering the relatively short experience of the 1980s. This line of research tries to identify a method of filtering the oil price signal that expresses asymmetric and non-linear influences such as adjustment costs resulting from sectoral imbalances or the postponement of irreversible investment decisions when oil price variations generate uncertainty. Lee, Ni and Ratti (1995) and Hamilton (1996) proposed specifications intended to integrate the "surprise factor" associated with oil price changes, while Ferderer (1996) used the price volatility of some petroleum products. But Hooker (1999) showed that these measures did not Grangercause GDP variations in the 1980-1998 sample. The third interpretation is that, around 1980, a break occurred in the relationship between the oil price and the macroeconomy (Hooker, 1996, 1999), due either to changes in the conduct of monetary policy in the Volcker-Greenspan era, or to the structural evolution of Western countries into postindustrialized societies. Finally, it is important to recall that the first two shocks occurred in a context where the global economy entered recession within a year. In the 2000s, the context is radically different: the global expansion was just started when oil prices started to rise in the beginning of the 2000s and inflation was low and falling. From this point of view, increasing oil prices may be viewed as the partial result of strong economic growth in many countries, especially in Asia (Bénassy-Quéré, Mignon and Penot, 2007). Such important growth has tempered or delayed the negative impact of high energy prices on the economic activity of oil-importing countries. In other words, the stage of the economic cycle played a role in mitigating the impact of an increase in oil prices: "with accelerating economic activity and expanding investment and production, companies have found it easier to absorb higher input costs - especially as profits have also been improving" (International Energy Agency, 2006). Another key difference between the economic context in the 1970s and today concerns the dependence on oil. Indeed, in the 1970s oilimport intensities were much higher than in the 2000s. These important differences between the 1970s and 1990s economic contexts are probably the main reasons explaining the apparent low impact of the oil price increase on economic activity today. 


\section{THE DATA AND THEIR PROPERTIES}

We consider a sample of 36 countries which can be classified in three groups. The first group contains the members of the Organization of the Petroleum Exporting Countries (OPEC) before the accession of Ecuador, namely Algeria, Angola, Indonesia, Iran, Iraq, Kuwait, Libya, Nigeria, Qatar, Saudi Arabia, United Arab Emirates and Venezuela. The second group is constituted by other major oil-exporting countries and includes: Brazil, Canada, Kazakhstan, Malaysia, Mexico, Oman, Norway, Russia and the UK. Finally, the third group is made of the following oil-importing countries: twelve members of the Eurozone $^{4}$, China, India and the US.

In order to study the impact of oil prices on economic activity, we consider four macroeconomic and one financial variables: Gross Domestic Product (GDP), Consumer Price Index (CPI), household consumption, unemployment rate and share prices. These variables are usual indicators for the business cycle. They were also chosen for practical considerations in the sense that they were available for almost all countries of our sample. Note that some of them, like GDP and unemployment, were also used in the seminal paper by Hamilton (1983). Data are annual and cover the period 1960 - 2005. Concerning oil, we consider real crude oil prices taken from the BP Statistical Review. For the other macroeconomic variables, data are generally taken from Word Bank, World Development Indicators (WDI). ${ }^{5}$ GDP and CPI series are available for all the 36 countries of our sample. This is also the case for the consumption series, except for Angola. Unemployment rate is available for all oil-importing countries except India, but only for three OPEC members (Algeria, Indonesia and Venezuela). Note that we have no data on unemployment rate for Oman. Finally, share prices are mainly from IFS, with the exception of Belgium, China, Germany, Greece, Kuwait, and the UK which are taken from Datastream. It should be noted that share prices are unavailable for $(i)$ all OPEC but Indonesia, Iran, Saudi Arabia and Venezuela and (ii) three oil-exporting countries: Kazakhstan, Oman and Russia. All the data are expressed in logarithmic real terms (using CPI as deflator), and CPI and share price series are based in $2000 .^{6}$

We first proceed to the application of standard unit root tests (Augmented Dickey-Fuller, Phillips-Perron and Kwiatkowski et al., KPSS) tests. Recall that the first two tests are based on the null hypothesis of a unit root, while the KPSS test considers the null of no unit root. With some exceptions, all our considered series appear to be integrated of order one, which is a standard result in the literature for such series.

We also implement panel unit root tests. The main advantage of nonstationary panel procedures is that they increase the span of the data by including information from various

\footnotetext{
4 Austria, Belgium, Finland, France, Germany, Greece, Ireland, Italy, Luxembourg, Netherlands, Portugal and Spain.

5 There are however some exceptions. GDP series for Iraq and Qatar are extracted from IMF, International Financial Statistics (IFS) and German CPI series is taken from Datastream. Concerning consumption series, some of WDI data have been completed using IFS: Iraq, Kuwait, Libya, Nigeria, Qatar and Saudi Arabia. For unemployment rates, data for the following countries are taken from Datastream: Austria, Canada, Finland, Germany, Greece, Indonesia, Malaysia, Norway, UK and US.

${ }^{6}$ Note that to transform some series expressed in local currency unit into USD, we used the USD bilateral exchange rate series extracted from IFS.

${ }^{7}$ Results are not reported here but are available upon request to the authors.
} 
countries and so raise the power of unit root and cointegration tests. Moreover, they can be useful for distinguishing statistical properties among different groups of countries. Here, we consider four panel unit root tests, all of them being based on the null hypothesis of a unit root. Levin and Lin $(1992,1993)$ and Breitung (2000) tests are based on a common unit root process. The hypothesis that the autoregressive parameters are common across individuals is a rather restrictive assumption on the dynamics of the series under the alternative hypothesis. For this reason, we also consider two other tests. The IPS (Im, Pesaran and Shin, 2003) test allows for heterogeneity in the value of the autoregressive coefficient under the alternative hypothesis. Thus, under the alternative hypothesis, some series may be characterized by a unit root, while some other series can be stationary. Like IPS, the Maddala and Wu (1999) test (MW) is not based on the restrictive assumption that the autoregressive coefficient is the same across countries. This test is a non-parametric Fisher-type test that combines the p-values from individual unit root tests.

According to the results in Tables A1 to A3 in the Appendix, all the considered series are integrated of order 1. Indeed, the unit root null hypothesis is never rejected when series are considered in logarithms, while it is rejected when series are in logarithmic first differences. There are some exceptions, such as OPEC CPI, and GDP and consumption series for oilimporting countries. For these three series, the Levin and Lin (LL) test does not reject the null hypothesis. However, these results can not be considered as representative, since all the other tests always reject the null and since the LL test is based on the restrictive assumption of homogeneity. On the whole, and whatever the considered group of countries, our results indicate that all series are integrated of order 1, confirming the results obtained in a time series framework.

\section{SHORT-TERM ANALYSIS}

\subsection{Causality tests}

In order to investigate the short-term links between oil prices and the other variables, we first proceed to Granger causality tests. Since our series are integrated or order 1, these tests are applied to series in first differences. Results are reported in Tables A4 to A6 in the Appendix.

According to these results, the direction of causality generally runs from oil prices to the other variables. There are however some exceptions such as causality from GDP to oil prices for Saudi Arabia, UK and to a less extent Qatar, and causality from unemployment to oil prices for four oil-importing countries (China, Greece, Spain and the US). ${ }^{8}$ It should be noted that these results are in accordance with those of Barsky and Kilian (2004). Indeed, while the majority of the literature assumes exogeneity of oil prices with respect to the macroeconomic and financial variables, Barsky and Kilian (2004) have suggested that a reverse relationship may exist where macroeconomic variables cause oil price movements (see also Ewing et al., 2007).

\footnotetext{
${ }^{8}$ To check that these causality were not spurious, we also run trivariate causality tests for the CPI, GDP and consumption series using values of these indicators for the whole world (global series were unavailable for unemployment and share prices). Overall, the bivariate results were confirmed.
} 
Concerning the causality running from oil prices to the macroeconomic and financial variables, the results can be summarized as follows. First, the impact of oil prices on consumption is generally weak, except for Venezuela and Spain. Second, there is a great influence of oil prices on the unemployment rate in the US, Luxembourg, France, Canada and Venezuela. Third, turning to the relation between oil prices and GDP, an interesting result is that there is no causality running from oil prices for the group of oil-exporting countries. In the two other groups, there exists causality for Iraq, Kuwait, China, Luxembourg, and to a less extent Belgium, France, Spain and the US. The fact that oil prices do not Granger-cause GDP in the group of non-OPEC oil-exporting countries might result from different reasons because this group of countries is really heterogeneous and represents a large share in world oil production. For some of them, oil exports were not important enough (over our sample) compared to the rest of the economy to determine changes in aggregate GDP (UK, Canada, Brazil). Others did not behave like market economies (Russia, Kazakhstan). Norway tries to protect herself from the volatility of oil prices by saving a part of the oil rent.

Fourth, the causality between oil prices and CPI mainly exists for OPEC and oil-exporting countries. Oil prices have a large influence on CPI for United Arab Emirates, UK, Mexico and Libya. This probably comes from the recycling of oil revenues by the governments and the associated increase in their spendings, which creates inflation. On the other hand, since the second oil price shock, oil importing countries' central bank try to keep oil price rises to pass through into core inflation.

Finally, one of the most interesting result concerns the strong influence of oil price movements on share prices on the short run. This is the case for non-OPEC groups of countries, with a particular importance for the oil-exporting countries. Indeed, oil prices affect stock markets in Mexico, Norway, UK and Malaysia. This situation is also observed for five oil-importing countries, namely Belgium, France, Spain, Netherlands and the US. In order to appreciate the dynamics of this link between oil and share prices on the short run, it may be interesting to calculate rolling correlations between the two series. Figure 1 reports the rolling correlations on five years for six countries. ${ }^{9}$ It is worth noting that the correlations follow an increasing trend, from negative to positive values, especially for Mexico, Norway, UK and France, suggesting that oil and stock markets are highly linked.

\footnotetext{
${ }^{9}$ Rolling correlations are calculated on series in logarithmic first differences. Note that we have also calculated rolling correlations for 3, 4 and 10 years. Since the results were very similar, only the graphs corresponding to a window of five years are reported.
} 


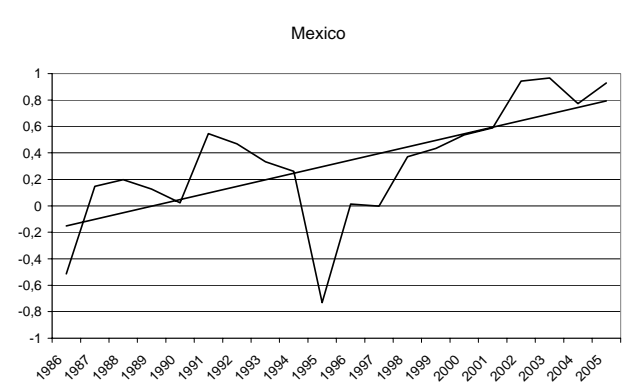

UK

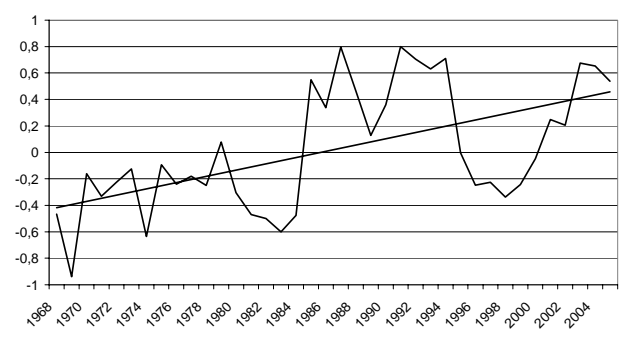

Spain

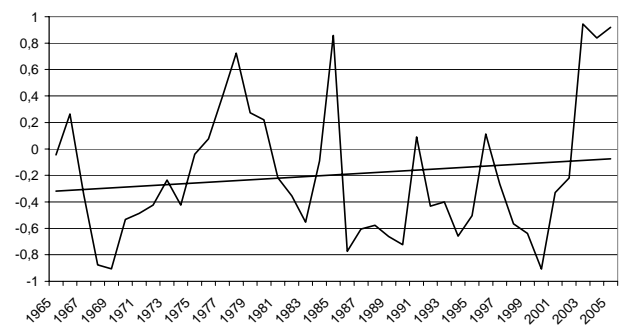

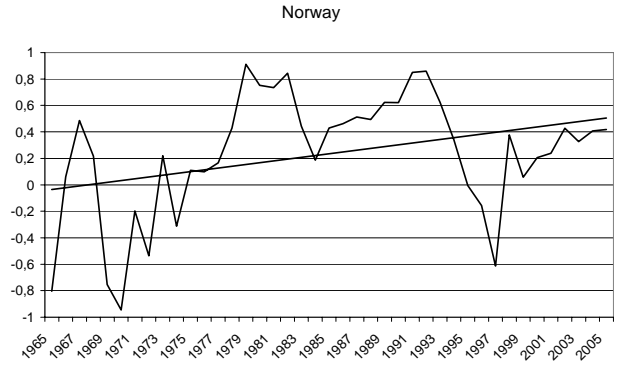

France

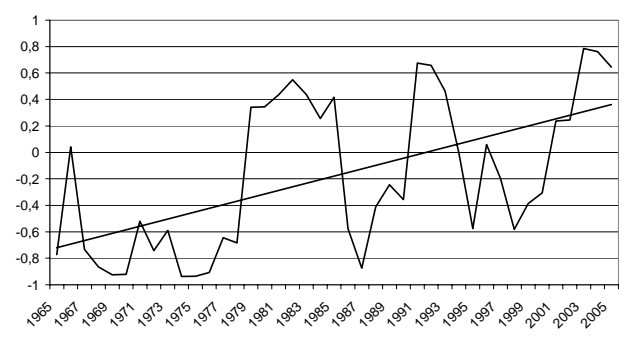

USA

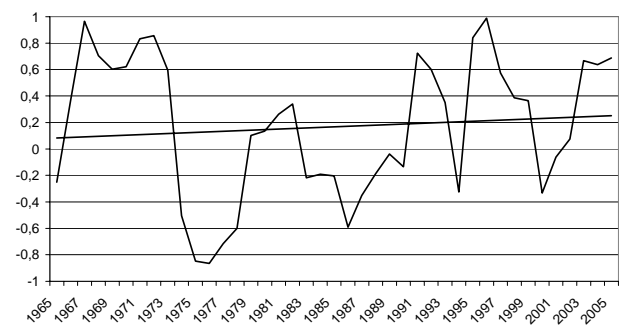

Figure 1. Rolling correlations between oil prices and share prices.

\subsection{Cyclical correlations}

The cyclical correlations between oil prices and macroeconomic and financial variables provide interesting information about their interactions as well. Following Hodrick and Prescott (1980) and Kydland and Prescott (1990), we decompose our time series into longrun and business cycle components by applying the Hodrick-Prescott filter (with a parameter of 100). Then, we compute the cross correlations between the cyclical component of oil prices (denoted $o$ ) and the cyclical components of the other series (denoted $y$ ). The correlation coefficient between $o(t)$ and $y(t+j), \rho(j)$, where $j=0, \pm 1, \pm 2$, $\pm 3, \pm 4, \pm 5$, measures the degree of comovement of oil prices with economic activity variables over the business cycle (Ewing and Thompson, 2007). This approach enables to examine the dynamics of the comovements of the short-run components by providing information about both their strength and their synchronization. Following Fiorito and Kollintzas (1994), we consider that the two cyclical components are strongly correlated, weakly correlated, or uncorrelated for a shift $j$ based on $0.23 \leq|\rho(j)|<1,0.10 \leq|\rho(j)|<0.23$, $0 \leq|\rho(j)|<0.10$, respectively. If the cross correlation, $\rho(j)$, is positive, zero or negative, then 
oil prices are procyclical, acyclical or countercyclical respectively. Further, if $|\rho(j)|$ is important (larger than 0.23 or larger than 0.10 ) for a positive, zero, or negative value of $j$, then the cycle of crude oil prices is leading the other cycle by $j$ periods, is synchronous, or is lagging the other cycle by $j$ periods, respectively.

The results globally corroborate those of the Granger causality tests and provide a complementary picture. The main conclusions can be synthesized as follows: ${ }^{10}$

- Although they are net exporters, Brazil, Canada and the United Kingdom generally behave like oil-importing countries, which is consistent with the moderate share of petroleum industries in their economy.

- Concerning CPI, we observe a rather natural mechanism: almost everywhere, CPI leads countercyclically real oil prices which lead procyclically the CPI. The first link simply reflects the erosion of real oil prices by inflation and the series are correlated for most of the countries (strongly for 9 countries); the strongest correlations correspond usually to a delay of 3 years. As for the second link, oil prices lead procyclically the CPI with a strong correlation mostly in the group of oil-importing countries, in Canada and in the UK. The strongest correlations are associated to delays from 1 to 2 years, but the comovement might be instantaneous in some countries (the USA for example) and long-lasting in some countries (up to 5 years in France, Italy, Portugal and Spain). This result seems to contradict the Granger tests but the failure to reject the hypothesis of no causality might be linked to the structural break in monetary policy that occured at the time of the second oil price shock.

- Concerning the other macroeconomic variables, we observe two behaviors. On the one hand, for the group of oil-importing countries plus Brazil, Canada and the UK, oil prices lead procyclically unemployment (an oil price increase tends to rise the unemployment rate) and countercyclically consumption and GDP whereas, symmetrically, oil prices lag consumption (procyclically), GDP (procyclically) and unemployment (countercyclically). On the other hand, for OPEC, oil prices lead procyclically consumption and sometimes GDP (Saudi Arabia, United Arab Emirates, Qatar notably). For the other oil-exporting countries, crude prices are generally acyclical with macroeconomic variables. The two behaviors seem logical. A growth in economic activity in oil-importing countries leads to higher oil demand. This causes crude prices to rise, which in turn leads to a slowdown in economic activity for importers; for exporters, this leads to an increase in government spending that feeds consumption and potentially GDP if the growing oil income is not totally recycled into imports and if the increase in consumption triggers a rise in domestic production. For oil-importing countries, the dynamics of the slowdown is not identical everywhere. In some countries, we observe a progression. For example, in France, higher oil prices lead first a rise in the CPI (strongest correlation for a lag of 1 year), then a decrease in GDP (strongest correlation for a lag of 2 years) and finally a contraction in consumption and a growth in unemployment (strongest correlations for lags of 3 to 4 years). The same kind of process appears for the Netherlands or Spain. On the other

\footnotetext{
${ }^{10}$ To save space, we only report some selected results concerning cyclical correlations. Table A7 in the Appendix reports cyclical correlations between oil prices and GDP and Table A8 displays the correlations between oil prices and share prices. Finally, as an illustration, Tables A9 and A10 report cyclical correlations between oil prices and the different variables for two specific countries: the US and Spain, respectively.
} 
hand, it is much faster in some countries like the US, where the CPI, unemployment, the GDP and consumption are most strongly correlated for a lag of 1 year, or the UK.

- Turning to share prices, the results confirm the Granger causality tests. Oil prices lead countercyclically share prices for almost every country but with varying lags. Nonetheless, the correlations are smaller than 0.10 (in absolute value) for OPEC.

\section{LONG-TERM ANALYSIS}

\subsection{Time series cointegration tests}

To apprehend the long-term links between oil prices and the various macroeconomic and financial variables, we first proceed to Johansen trace cointegration test. This test is based on the null of no cointegration between oil prices and the considered series. If the series are found to be cointegrated, we then implement Granger causality tests (between series in levels). ${ }^{11}$ Indeed, it is well known that the existence of a cointegrating relationship between two variables means that at least one of the two variables Granger-causes the other.

In order to avoid too many tables, we summarize the results in the following way. Table 1 reports the results of both cointegration and causality tests; causality tests being implemented only if series were found to be cointegrated. More specifically, the Table displays the countries for which a cointegrating relationship is found, together with the direction of the causality. The following main conclusions emerge.

It is worth noting that numerous cointegrating relationships are found for oil-importing countries. Interestingly, for most of them the causality generally runs from oil prices to the macroeconomic and financial variables, confirming the results obtained in the short term. This is always the case when considering GDP and share prices series. For these two series, the impact of an increase in oil prices is always negative. For instance, in Italy, a $10 \%$ oil price increase leads to a $-0.7 \%$ decrease in GDP. It should be noted that oil prices also have a large impact on unemployment rates for these countries, the impact being globally negative. In other words, an oil price increase tends to generate, on the long run, a decrease in the unemployment rate, confirming the result obtained by Keane and Prasad (1996). This is especially the case for Spain and Greece. On the whole, oil prices seem to play a major key role on the economic activity of several oil-importing countries.

Turning to OPEC, GDP and oil prices evolved together in the long-run for five countries, and the causality is positive and runs from oil prices to GDP for Iraq, Qatar and United Arab Emirates. For the two other countries, Iran and Saudi Arabia, the causality runs in both directions. Interestingly, there is an influence of oil prices on CPI in the United Arab Emirates.

Considering other oil-exporting countries, the main interesting result lies in the causality from oil prices to share prices for all the countries for which a cointegrating relationship was found. As for oil-importing countries, this relationship is negative meaning that an oil

\footnotetext{
${ }^{11}$ Compared to Section 4, the difference is that Granger causality tests are applied to series in levels and not in first-differences.
} 
price increase leads to a decrease in share prices. As an example, a $10 \%$ increase in oil prices leads to a $3.7 \%$ decrease in UK share prices and $4.5 \%$ for Malaysia. It is also interesting to note that there is an impact of economic activity on oil prices for these countries. Indeed, there is causality from GDP to oil prices and causality from unemployment rate to oil prices for some countries.

On the whole, the majority of long-run relationships concerns GDP, unemployment rate and share prices. Indeed, GDP and oil prices evolve together in the long run for 12 countries, belonging to the three groups. The relationships relating to unemployment rates and share prices only concern non-OPEC members. Concerning share prices, we can note that the causality is negative and always runs from oil prices to stock markets.

Table 1. Cointegration and causality tests (series in levels).

\begin{tabular}{|c|c|c|c|c|c|}
\hline & "GDP & CPI & Consumption & $\begin{array}{l}\text { Share } \\
\text { prices }\end{array}$ & $\begin{array}{l}\text { Unemploy. } \\
\text { rate }\end{array}$ \\
\hline OPEC & $\begin{array}{c}\text { Iran } \\
\text { Iraq } \\
\text { Qatar } \\
\text { Saudi Arabia } \\
\text { United Arab } \\
\text { Emirates } \\
\end{array}$ & $\begin{array}{c}\text { Kuwait } \\
\text { United Arab } \\
\text { Emirates }\end{array}$ & Venezuela & & \\
\hline $\begin{array}{c}\text { Other } \\
\text { exporting }\end{array}$ & $\begin{array}{l}\text { Brazil } \\
\text { Oman }\end{array}$ & Norway & & $\begin{array}{c}\text { Canada } \\
\text { Malaysia } \\
\text { UK }\end{array}$ & $\begin{array}{c}\text { Canada } \\
\text { Norway } \\
\text { UK }\end{array}$ \\
\hline Importing & $\begin{array}{c}\text { Austria } \\
\text { Belgium } \\
\text { France } \\
\text { Italy } \\
\text { Netherlands }\end{array}$ & Finland & $\begin{array}{c}\text { Greece } \\
\text { Luxembg } \\
\text { Netherland. }\end{array}$ & $\begin{array}{c}\text { Belgium } \\
\text { France } \\
\text { Italy }\end{array}$ & $\begin{array}{c}\text { Austria } \\
\text { Belgium } \\
\text { China } \\
\text { France } \\
\text { Greece } \\
\text { Portugal } \\
\text { Spain }\end{array}$ \\
\hline
\end{tabular}

In bold: causality runs from oil prices to the considered variable. In italics: causality runs from the considered variable to oil prices. Standard: causality in both directions.

\subsection{Panel cointegration tests}

To complement our results, we now implement panel cointegration tests. We first consider the seven tests proposed by Pedroni $(1999,2004)$. These tests are based on the null hypothesis of no cointegration. Among the 7 Pedroni's tests, 4 are based on the within dimension (panel cointegration tests) and 3 on the between dimension (group mean panel cointegration tests). Group mean panel cointegration statistics are more general in the sense that they allow for heterogeneous coefficients under the alternative hypothesis. Results are reported in Tables 2 to 4 . 
On the influence of oil prices on economic activity and other macroeconomic and financial variables

Table 2. Pedroni panel cointegration tests, OPEC

\begin{tabular}{llllllll}
\hline \hline \multicolumn{3}{c}{ Panel cointegration tests } & & \multicolumn{4}{l}{ Group mean cointegration tests } \\
\hline & v-stat & rho-stat & PP-stat & ADF-stat & rho-stat & PP-stat & ADF-stat \\
OIL / GDP & $-1.03(0.23)$ & $1.28(0.17)$ & $1.06(0.22)$ & $1.35(0.16)$ & $\mathbf{2 . 0 0 ( \mathbf { 0 . 0 5 } )}$ & $1.52(0.12)$ & $\mathbf{1 . 9 1}(\mathbf{0 . 0 6})$ \\
OIL / CPI & $-0.76(0.29)$ & $1.09(0.22)$ & $0.87(0.27)$ & $1.08(0.22)$ & $\mathbf{2 . 2 9}(\mathbf{0 . 0 2})$ & $\mathbf{1 . 9 5}(\mathbf{0 . 0 6})$ & $\mathbf{2 . 1 5}(\mathbf{0 . 0 4})$ \\
OIL / Cons. & $-0.34(0.37)$ & $0.60(0.33)$ & $0.41(0.36)$ & $0.51(0.35)$ & $1.26(0.18)$ & $0.87(0.27)$ & $0.85(0.27)$ \\
OIL / Share & $-0.87(0.27)$ & $\mathbf{2 . 6 3 ( 0 . 0 1 )}$ & $0.94(0.38)$ & $0.38(0.37)$ & $\mathbf{2 . 5 4}(\mathbf{0 . 0 1})$ & $0.35(0.37)$ & $-0.61(0.33)$ \\
OIL/ Unem. & $-0.88(0.27)$ & $\mathbf{1 . 7 8 ( 0 . 0 8 )}$ & $1.49(0.13)$ & $1.08(0.22)$ & $\mathbf{1 . 8 9}(\mathbf{0 . 0 6})$ & $1.25(0.18)$ & $0.42(0.36)$ \\
\hline \hline
\end{tabular}

p-values are given in parentheses.

Table 3. Pedroni panel cointegration tests, other oil-exporting countries.

\begin{tabular}{|c|c|c|c|c|c|c|c|}
\hline & \multicolumn{4}{|c|}{ Panel cointegration tests } & \multicolumn{3}{|c|}{ Group mean cointegration tests } \\
\hline & $v$-stat & rho-stat & PP-stat & $A D F$-stat & rho-stat & PP-stat & $A D F$-stat \\
\hline$O I L / G D P$ & $-0.86(0.27)$ & $1.04(0.23)$ & $0.92(0.26)$ & $1.47(0.13)$ & $2.07(0.04)$ & $1.91(0.06)$ & $2.39(0.02)$ \\
\hline$O I L / C P I$ & $-0.85(0.27)$ & $1.50(0.13)$ & $1.49(0.13)$ & $1.56(0.11)$ & $2.68(0.01)$ & $2.81(0.007)$ & $2.92(0.005)$ \\
\hline OIL / Cons. & $-0.63(0.32)$ & $0.84(0.28)$ & $0.59(0.33)$ & $0.77(0.29)$ & $1.77(0.08)$ & $1.38(0.15)$ & $1.48(0.13)$ \\
\hline OIL / Share & $0.77(0.29)$ & $2.07(0.04)$ & $0.57(0.34)$ & $1.36(0.15)$ & $2.95(0)$ & $1.45(0.13)$ & $2.39(0.02)$ \\
\hline OIL / Unem. & $-0.44(0.36)$ & $3.60(0)$ & $1.12(0.21)$ & $2.66(0.01)$ & $4.07(0)$ & $2.03(0.05)$ & $1.89(0.06)$ \\
\hline
\end{tabular}

p-values are given in parentheses. 
Table 4. Pedroni panel cointegration tests, oil-importing countries.

\begin{tabular}{|c|c|c|c|c|c|c|c|}
\hline & \multicolumn{4}{|c|}{ Panel cointegration tests } & \multicolumn{3}{|c|}{ Group mean cointegration tests } \\
\hline & $v$-stat & rho-stat & PP-stat & $A D F$-stat & rho-stat & PP-stat & $A D F$-stat \\
\hline$O I L / G D P$ & $-1.13(0.20)$ & $0.95(0.25)$ & $0.74(0.30)$ & $1.52(0.12)$ & $2.34(0.02)$ & $1.95(0.05)$ & $2.72(0.01)$ \\
\hline$O I L / C P I$ & $-0.86(0.27)$ & $2.18(0.03)$ & $2.65(0.01)$ & $2.62(0.01)$ & $3.52(0)$ & $4.12(0)$ & $4.03(0)$ \\
\hline OIL / Cons. & $-1.07(0.22)$ & $0.97(0.24)$ & $0.73(0.30)$ & $1.52(0.12)$ & $2.32(0.02)$ & $1.84(0.07)$ & $2.71(0.01)$ \\
\hline OIL / Share & $0.61(0.33)$ & $2.94(0.005)$ & $0.57(0.33)$ & $2.85(0.006)$ & $4.55(0)$ & $2.40(0.02)$ & $4.13(0)$ \\
\hline OIL / Unem. & $-0.61(0.33)$ & $3.20(0.002)$ & $1.00(0.24)$ & $1.41(0.15)$ & $3.22(0.002)$ & $1.07(0.22)$ & $1.00(0.24)$ \\
\hline
\end{tabular}


As it is frequently the case, the results issued from Pedroni's tests are mixed. If we give more importance to group-mean tests which allow for heterogeneity, we can draw the following conclusions:

- OPEC. Oil prices and CPI are cointegrated according to the three group-mean tests. A long-term relationship also exists between oil prices and GDP for two tests. These results globally confirm those obtained in a time series context. There is weak evidence in favor of cointegration between oil and share prices and oil prices and unemployment rate. These results are however not highly representative since the samples are very small. Indeed, due to data availability, only four countries are considered for the link between oil and share prices (Indonesia, Iran, Saudi Arabia and Venezuela), and only three countries for the relationship between oil prices and unemployment rate (Algeria, Indonesia and Venezuela).

- Other oil-exporting countries. More long-term relationships between oil prices and macroeconomic aggregates exist for this group of countries. Indeed, according to the three group-mean tests, oil prices are cointegrated with the three following variables: GDP, CPI and unemployment rate. A long-term relationship can also be detected between oil and share prices. These results are particularly interesting since they put forward that oil prices and economic activity are linked in the long run.

- Oil-importing countries. Four long-term relationships are detected here. First, all the tests but one detect a long-run link between oil prices and CPI. Second, there is also a strong long-term relationship between oil and share prices. This result is particularly interesting since it highlights the links existing between the two markets on the long run. Finally, a cointegrating relationship exists between (i) oil prices and GDP and (ii) oil prices and consumption.

These results are globally confirmed by Kao (1999) cointegration tests (Table 5). As for the Pedroni's tests, Kao's tests are based on the null hypothesis of no cointegration. However, they are less general than the Pedroni's tests since cointegrating vectors are supposed to be homogenous across individuals. As reported in Table 5, all the cointegrating links detected by Pedroni's test are also obtained with Kao's tests. Three more cointegrating relationships are found between oil prices and (i) consumption for OPEC and other oil-exporting countries and (ii) unemployment rate in oil-importing countries.

Table 5. Kao residual cointegration test.

\begin{tabular}{cccc}
\hline & OPEC & Other exporting & Importing \\
\hline OIL / GDP & $\mathbf{- 1 . 8 2 ( \mathbf { 0 . 0 3 } )}$ & $\mathbf{- 1 . 4 6 ( \mathbf { 0 . 0 7 } )}$ & $\mathbf{- 2 . 1 0 ( \mathbf { 0 . 0 1 } )}$ \\
OIL / CPI & $\mathbf{- 1 . 4 4 ( \mathbf { 0 . 0 7 } )}$ & $\mathbf{- 1 . 3 8 ( 0 . 0 8 )}$ & $\mathbf{- 2 . 1 6 ( \mathbf { 0 . 0 1 } )}$ \\
OIL / Consumption & $\mathbf{- 1 . 5 2 ( \mathbf { 0 . 0 6 } )}$ & $\mathbf{- 1 . 5 1 ( \mathbf { 0 . 0 6 } )}$ & $\mathbf{- 2 . 2 2 ( \mathbf { 0 . 0 1 } )}$ \\
OIL / Share prices & $-0.004(0.49)$ & $-0.67(0.25)$ & $\mathbf{- 1 . 6 5 ( \mathbf { 0 . 0 5 } )}$ \\
OIL / Unemployment rate & $-0.45(0.32)$ & $\mathbf{- 1 . 5 7 ( \mathbf { 0 . 0 5 } )}$ & $\mathbf{- 1 . 8 9 ( \mathbf { 0 . 0 3 } )}$ \\
\hline
\end{tabular}

p-values are given in parentheses. 


\subsection{Convergence to the long-term target}

It may be interesting to estimate vector error-correction models in order to describe the dynamic adjustment of the variables to long-run equilibrium. From these estimations, it is possible to evaluate the adjustment speed to the equilibrium or, equivalently, the half-life of deviations from the equilibrium. Figure $2 \mathrm{a}$ to $2 \mathrm{c}$ report the half-lives corresponding to GDP, share prices and unemployment rate, respectively. The adjustment speed of the GDP to its long-term value is important for non-OPEC oil-exporting countries, and is lower for the other countries, especially for Iran, United Arab Emirates, Belgium and Italy. Turning to the unemployment rate, the adjustment speed is quite homogenous with a mean half-life of around 3 years, excluding UK and Greece. For these two countries, and especially for UK, the half-life is very high, meaning that the adjustment speed is very low and that there is almost no mean reversion. Finally, considering share prices, it is worth noting that the speeds of adjustment are generally high, half-lives being lower than 2 years, with the exception of UK for which no mean reversion seems to exist. This last result tends to confirm the aforementioned fact according to which there exists an important link between oil prices and share prices in the short run.

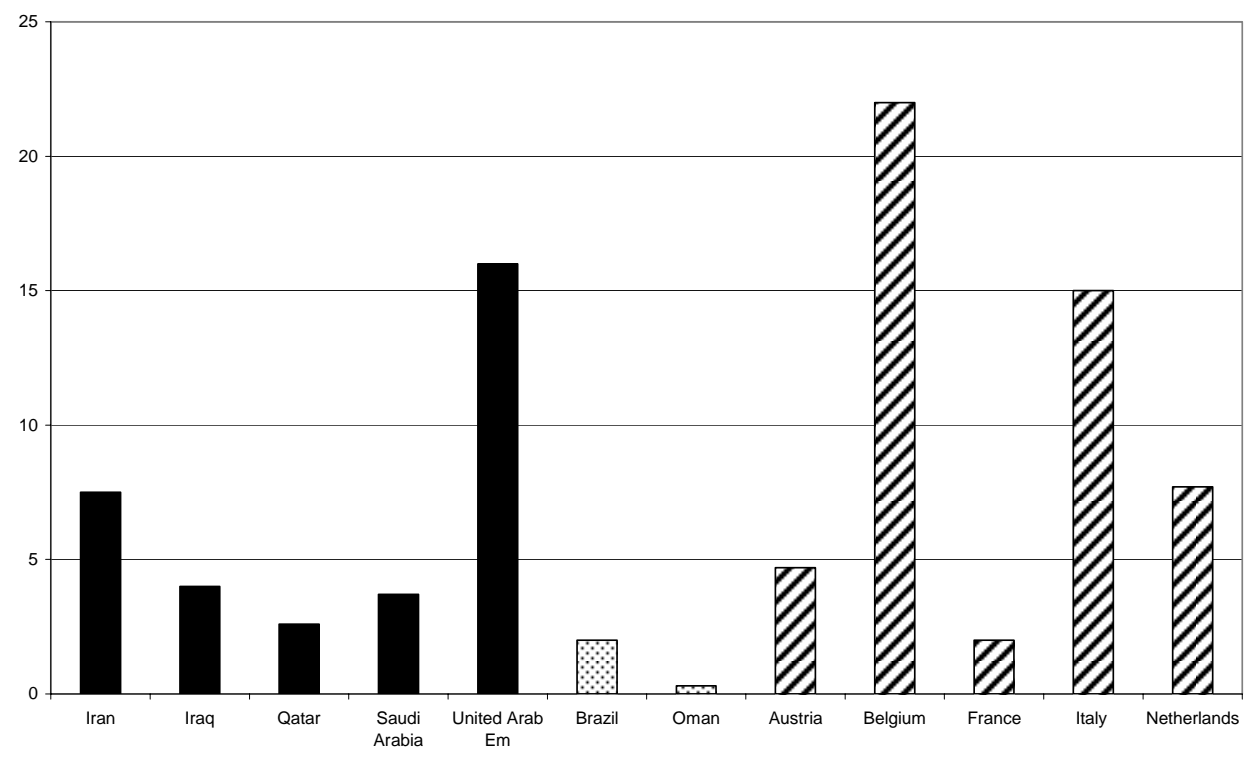

Figure 2a. Half-lives, GDP (in years). 
On the influence of oil prices on economic activity and other macroeconomic and financial variables

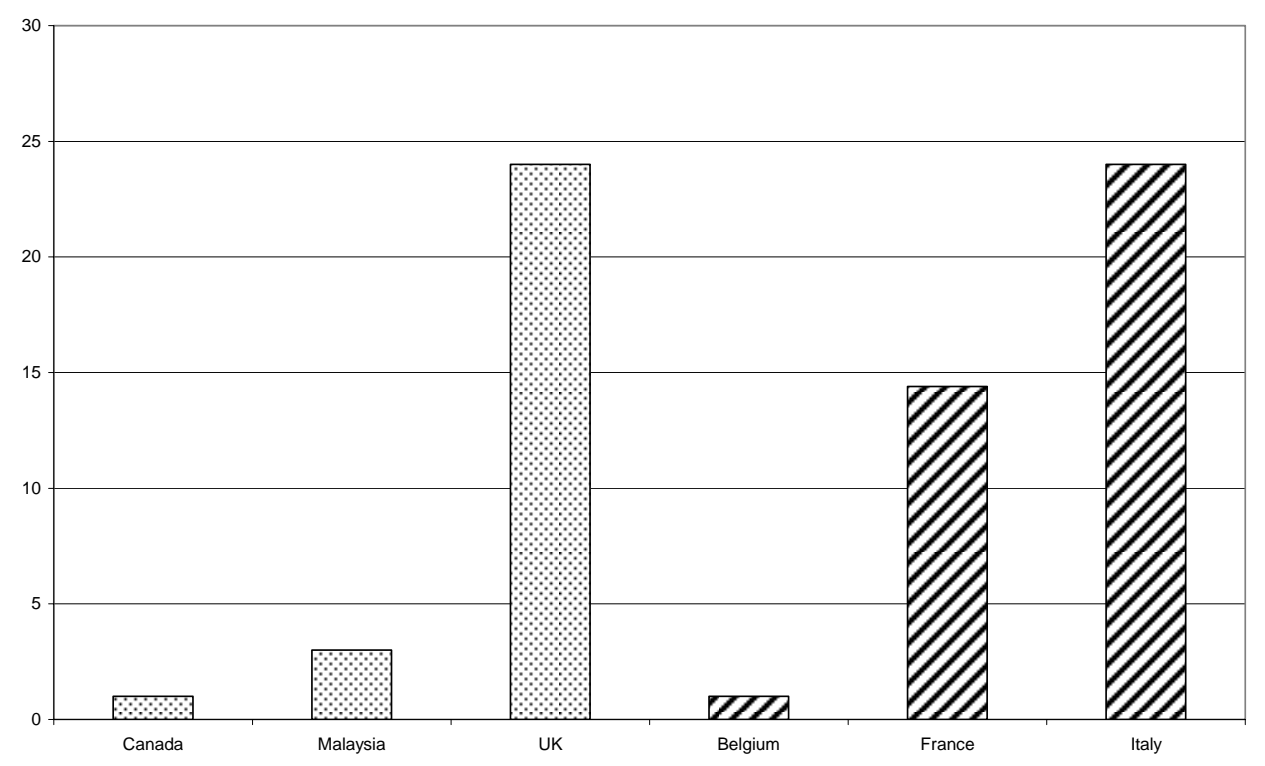

Figure 2b. Half-lives, share prices (in months).

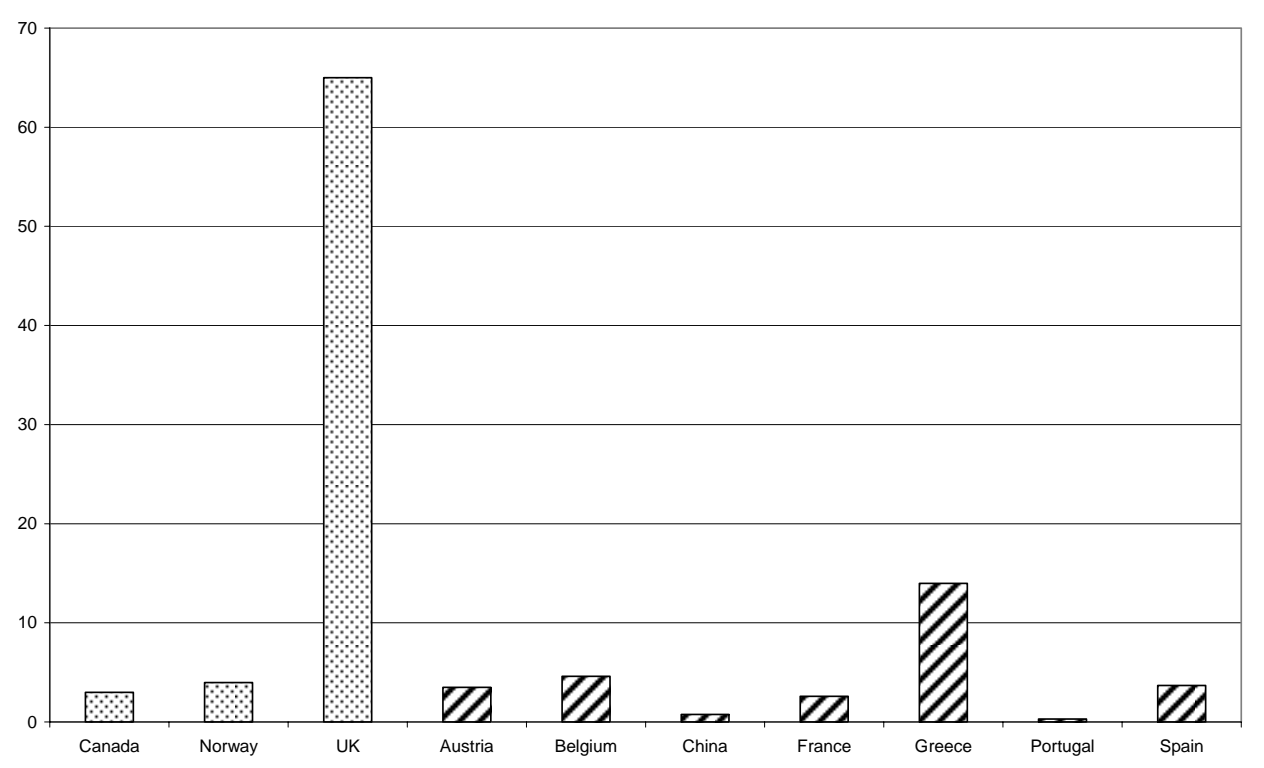

Figure 2c. Half-lives, unemployment rate (in years). 


\section{MUlTiVARIATE ANALYSIS: A FOCUS ON THE US CASE}

In order to observe the transmission channels by which oil prices affect macroeconomic activity, we complement our analysis by estimating a multivariate model intended to represent the mechanisms of propagation of an oil price change through the US economy. We focus on the US case since our series are available on a too short common time sample for other countries, because of missing data on either unemployment or share prices in the 1960s. Further, this enables to consider as well short-run interest rates which could not be used in the bivariate analysis devoted to international comparison because of the brevity of the records in many countries.

So, our endogenous variables of interest are the logarithm of real oil prices $(O I L)$, the real short-run interest rate $(F F R)$, the logarithm of real GDP $(G D P)$, the logarithm of real consumption expenditures (CONS), the logarithm of share prices in real terms (SHAR) and the unemployment rate $(U N) .{ }^{12}$ As for the bivariate analysis, data are annual and cover the 1962 to 2005 period.

Like the bivariate cointegration tests, the multivariate ones indicate no cointegration between the considered series. Consequently, we estimate a vector autoregressive model (VAR). Its general form is:

$$
\mathbf{A}(\mathbf{L}) \cdot \mathbf{X}_{\mathbf{t}}=\boldsymbol{\varepsilon}_{\mathrm{t}}
$$

where $\mathbf{A}(\mathrm{L})$ is a polynomial matrix in the lag operator $\mathrm{L}, \mathbf{X}$ is the column vector of endogenous variables (all are in first differences) and $\varepsilon$ is a vector of innovations. The autoregressive structure chosen by minimizing the Schwarz Information Criterion (SIC) includes 2 lags. ${ }^{13}$

\footnotetext{
12 At first, we considered the logarithm of the CPI as well but the results were not reliable. As highlighted by the bivariate Granger-causality tests and the cyclical cross-correlations, oil prices affect US inflation positively and instantaneously with annual data. The vector modeling approach does not enable contemporaneous short-run interactions between endogenous variables. This was leading to a fallacious, negative, non-significant correlation between past oil prices and the CPI which was biasing the results. Consequently, we preferred to exclude the CPI from the multivariate model.

13 Note that this is consistent with the studies on quarterly data. Indeed, generally, the VAR models that aim at estimating the oil price-macroeconomy relationship include between 4 and 8 lags with quarterly data.
} 
On the influence of oil prices on economic activity and other macroeconomic and financial variables

Figure $3 a$

Response of $D(L O G(G D P))$ to Cholesky One S.D. D(LOG(OIL)) Innovation

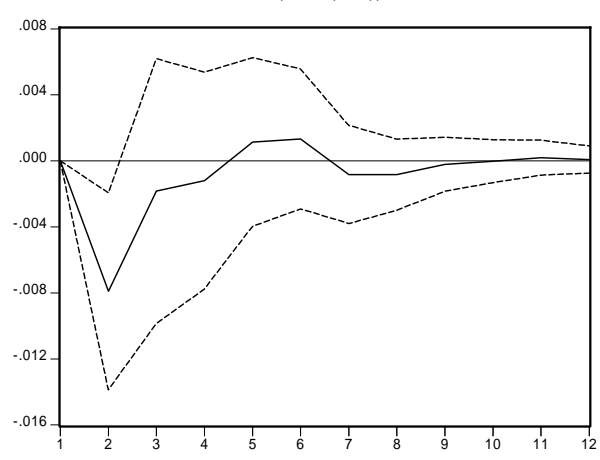

Figure $3 c$

Response of $\mathrm{D}(\mathrm{LOG}(\mathrm{CONS}))$ to Cholesky One S.D. D(LOG(OIL)) Innovation

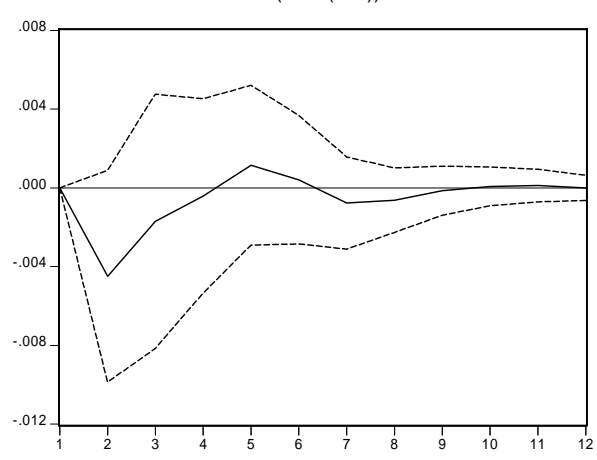

Figure $3 e$

Response of $D(F F R)$ to Cholesky One S.D. D(LOG(OIL)) Innovation

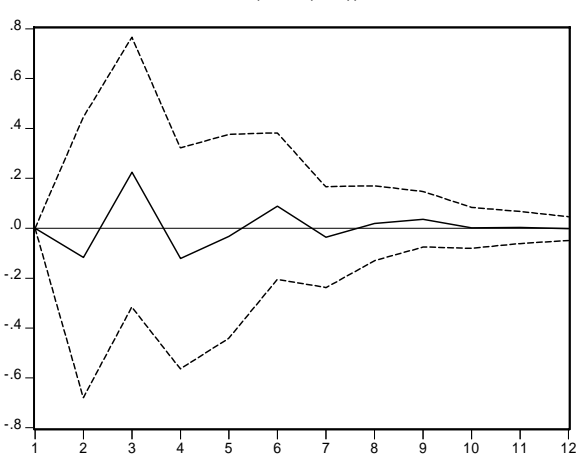

Figure $3 b$

Response of $D(U N)$ to Cholesky One S.D. D(LOG(OIL)) Innovation

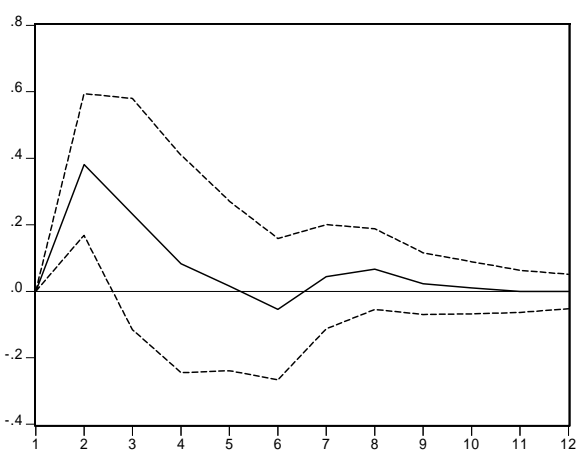

Figure $3 d$

Response of $\mathrm{D}(\mathrm{LOG}(\mathrm{SHAR}))$ to Cholesky One S.D. D(LOG(OIL)) Innovation

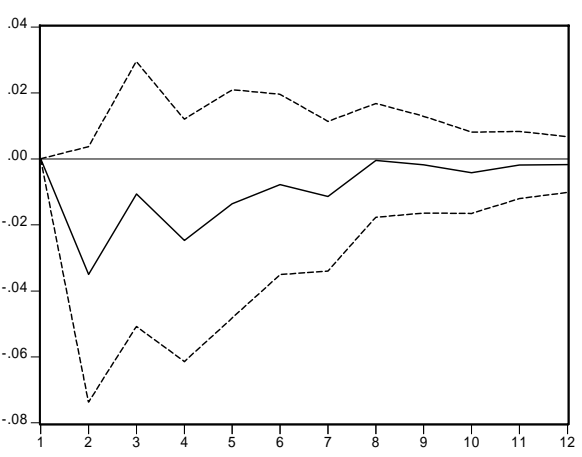

Figure $3 f$

Response of $\mathrm{D}(\mathrm{LOG}(\mathrm{OIL}))$ to Cholesky One S.D. D(LOG(OIL)) Innovation

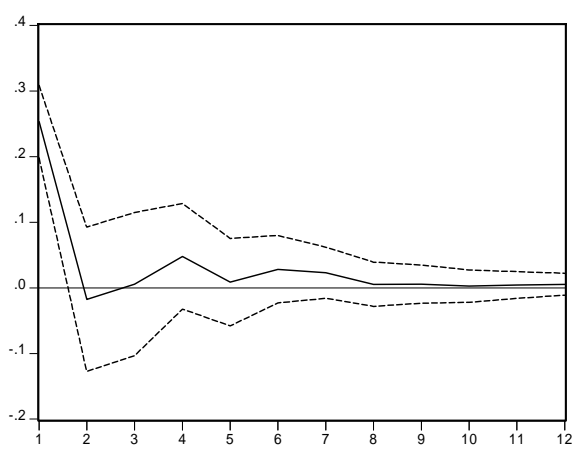

Figure 3. Impulse-response functions. 
We performed pairwise Granger-causality tests (Granger, 1969) to identify interactions between our variables (Table A11). It appears that oil prices cause GDP and unemployment. Further, we performed impulse-response analysis ${ }^{14}$ (Figures $3 \mathrm{a}$ to $3 \mathrm{f}$ ). The simulations confirm by and large the results of the bivariate analysis. The maximal impact of oil prices on the other variables occurs with a lag of one year, except for the real shortrun interest rate. Oil prices affect positively and significantly GDP, negatively and significantly unemployment, negatively but non-significantly consumption and share prices. The real short-run interest rate first decreases (because of the rise in inflation) and then increases, but we failed in simulating a significant effect (probably because of the instability of monetary policy over the sample and because of the stop-and-go policies of the 1970s).

Many studies have shown that the oil price-macroeconomy relationship has weakened since the first oil price shocks (Hooker, 1996, for example). Consequently, we estimated our multivariate model on subsamples to test for the stability of the results. This exercise corroborates previous results: the impact is stronger when the model is estimated over the 1962-1986 sample and weaker when the model is estimated over the 1986-2005 sample. ${ }^{15}$ More precisely, after one year, the elasticity of real GDP with respect to real oil prices is close to $-1.2 \%,-0.8 \%$ and $-0.2 \%$ over the $1962-1986$ sample, the $1962-2005$ sample and the 1986-2005 sample respectively. Further, oil prices Granger-cause share prices and consumption (at the $1 \%$ and the $5 \%$ significance levels respectively) and the impact on consumption of a shock becomes significant over the first subsample whereas they fail to Granger-cause any variable over the last subsample, and the impulse responses are no more significant.

Globally, our results corroborate previous results concerning the negative and 1-year delayed impact of real oil prices on real GDP (see, among others, Hamilton, 1983; Mork et al., 1994). They confirm as well the weakening of the relationship over time. As for the magnitude of the impact, our estimate lies rather at the bottom of the interval covered by published elasticities. Indeed, over the first subsample, our value is close to the ratio of oil purchases to GDP before the first oil price shock (1.14\% in 1970), which is consistent with Tobin's view (1980). Nonetheless, over the whole sample, our elasticity disconnects with the share of oil in value added and it seems that oil prices are no longer an important driver of business cycle fluctuations. Our values of $-1.2 \%,-0.8 \%$ and $-0.2 \%$ (over the 1962-1986 sample, the 1962-2005 sample and the 1986-2005 sample respectively) are close to the oil price-GDP elasticities calculated from simulations with the models from the FRB, the IMF, and the OECD, which lie between $-1 \%$ and $-0.1 \%$ (reported by Jones, Leiby and Paik, 2004).

\footnotetext{
${ }^{14}$ We checked for the sensibility of our results according to the ordering of the variables in the VAR: the simulations were not affected.

${ }^{15}$ Complete results are available upon request to the authors.
} 


\section{CONCLUSION}

In this paper, we have investigated the links between oil prices and various macroeconomic and financial variables for a large set of countries. Concerning the short term analysis, our results indicate that when causality exists, it generally runs from oil prices to the other considered variables. One of the most interesting results is relating to stock markets since our analysis indicates that there exists a strong causality running from oil to share prices, especially for oil-exporting countries. This result is confirmed by the calculation of cyclical correlations where oil prices are found to lead countercyclically share prices for almost every country. Turning to the long term analysis, the majority of long-run relationships concerns GDP, unemployment rate and share prices. Indeed, GDP and oil prices evolve together in the long run for twelve countries. The relationships between oil prices and unemployment rates or share prices only concern non-OPEC members. Concerning share prices, the causality is negative and always runs from oil prices to stock markets, putting forward the key role played by the oil market on financial activity.

The present analysis can be extended in several ways. Turning to the link between GDP and oil prices, it would be interesting to investigate the impact of the world demand and world economic growth on oil prices in order to analyze the current situation. Also, considering stock markets, examining sectoral stock indices would seem a promising approach. 


\section{REFERENCES}

Abel, A.B. and B.S. Bernanke (2001), Macroeconomics, Addison Wesley Longman Inc.

Barro, R.J. (1984), Macroeconomics, John Wiley \& Sons.

Barsky, R. and L. Kilian (2004), "Oil and the macroeconomy since the 1970s", NBER Working Paper 10855.

Bénassy-Quéré, A., Mignon, V. and A. Penot (2007), "China and the relationship between the oil price and the Dollar", Energy Policy 35, 5795-5805.

Blanchard, O.J. and J. Gali (2007), "The macroeconomic effects of oil shocks: Why are the 2000s so different from the 1970s?”, NBER Working Paper 13368.

Bohi, D.R. (1991), "On the macroeconomic effects of energy price shocks", Resources and Energy 13(2), 145-62.

Breitung, J. (2000), "The local power of some unit root tests for panel data", in B. Baltagi (ed.), Advances in Econometrics, Vol. 15: Nonstationary Panels, Panel Cointegration, and Dynamic Panels, Amsterdam: JAI Press, 161-178.

Brown, S.P.A. and M.K. Yücel (1999), "Oil prices and U.S. aggregate economic activity”, Federal Reserve Bank of Dallas Economic Review, 16-53.

Brown, S.P.A. and M.K. Yücel (2002), "Energy Prices and Aggregate Economic Activity: An Interpretative Survey", Quarterly Review of Economics and Finance 42, 193-208.

Bruno, M. and J. Sachs (1985), Economics of worldwide stagflation, Harvard University Press.

Burbidge, J. and A. Harrison (1984), "Testing for the effects of oil price rises using vector autoregression", International Economic Review 25, 459-484.

Caruth, A.A., Hooker, M.A. and A.J. Oswald (1998), "Unemployment equilibria and input prices: Theory and evidence from the United States", Review of Economics and Statistics 80, 621-628.

Darby, M.R. (1982), "The price of oil and world inflation and recession", American Economic Review 72(4), 738-751.

Darby, M.R. (1984), "The U.S. productivity slowdown: A case of statistical myopia", American Economic Review, 74(3).

Davis, S.J. and J. Haltiwanger (2001), "Sectoral job creation and destruction responses to oil price changes", Journal of Monetary Economics 48, 645-512.

De Gregorio, J., Landerretche, O. and C. Neilson (2007), "Another pass-through bites the dust? Oil prices and inflation", Mimeo.

Edelstein, P. and L. Kilian (2007), "Retail energy prices and consumer expenditures", Mimeo, University of Michigan. 
On the influence of oil prices on economic activity and other macroeconomic and financial

variables

El-Sharif, I., Brown, D., Burton, B., Nixon, B. and A. Russell (2005), "Evidence on the nature and extent of the relationship between oil prices and equity values in the UK", Energy Economics 27, 819-830.

Ewing, B.T. and M.A. Thompson (2007), "Dynamic cyclical components of oil prices with industrial production, consumer prices, unemployment and stock prices", Energy Policy 35, 5535-5540.

Ferderer, J.P. (1996), "Oil price volatility and the macroeconomy", Journal of Macroeconomics 18(1), 1-26.

Fiorito, R. and T. Kollintzas (1994), "Stylized Facts of Business Cycles in the G7 from a Real Business Cycle Perspective”, European Economic Review, 38, 235-269.

Fuhrer, J.C. (1995), “The Phillips Curve is alive and well”, New England Economic Review of the Federal Reserve Bank of Boston, March/April, 41-56.

Gordon, R.J. (1997), “The time-varying NAIRU and its implications for economic policy”, Journal of Economic Perspectives 11(1), 11-32.

Hamilton, J.D. (1983), “Oil and the Macroeconomy Since World War II", Journal of Political Economy 91, 228-248.

Hamilton, J.D. (1996), "What is happened to the oil price macroeconomic relationship?", Journal of Monetary Economics 38(2), 215-220.

Hamilton, J.D. (2005), “Oil and the macroeconomy”, Working Paper UCSD.

Herrera, A.M. and E. Pesavento (2007), "Oil price shocks, systematic monetary policy, and the great moderation", Michigan State University, Unpublished manuscript.

Hickman, B.G., Huntington, H.G. and J.L. Sweeney, eds. (1987), The Macroeconomic Impacts of Energy Shocks, Amsterdam: Elsevier Science Publishers, B.V., NorthHolland.

Hodrick, R.J. and E.C. Prescott (1980), "Post-War U.S. business cycles: An empirical investigation", Working Paper, Carnegie Mellon University.

Hooker, M.A. (1996), "What happened to the oil price macroeconomy relationship?", Journal of Monetary Economics 38, 195-213.

Hooker, M.A. (1999), "Are oil shocks inflationary? Asymmetric and nonlinear specifications versus changes in regime", Federal Reserve Board (FEDS), Working Paper 1999-65.

Hooker, M.A. (2002), "Are oil shocks inflationary? Asymmetric and nonlinear specifications versus changes in regime", Journal of Money, Credit and Banking 34(2), 540-561.

International Energy Agency (2006), World Energy Outlook.

Im, K.S., Pesaran, M.H. and Y. Shin (2003), "Testing for unit roots in heterogeneous panels", Journal of Econometrics 115, 53-74.

Jimenez-Rodriguez, R. and M. Sanchez (2005), "Oil price shocks and real GDP growth: Empirical evidence for some OECD countries", Applied Economics 37, 201-228. 
Jones, C.M. and G. Kaul (1996), “Oil and the stock markets”, Journal of Finance 51, 463491.

Jones, D.W. and P.N. Leiby (1996), "The macroeconomic impacts of oil price shocks: A review of literature and issues", Oak Ridge National Laboratory, xerox, 33 p.

Jones, D.W., Bjornstad, D.J. and P.N. Leiby (1997), "The findings of the D.O.E. workshop on economic vulnerability to oil price shocks: Summary and integration with the previous knowledge", Oak Ridge National Laboratory, xerox, 36 p.

Jones, D.W., Leiby, P.N. and I.K. Paik (2002), "Oil price shocks and the macroeconomy: What has been learned since 1996?", Proceedings of the 25th Annual IAEE International Conference, 26-29 June 2002, Aberdeen, Scotland, 10 p.

Jones, D.W., Leiby, P.N. and I.K. Paik (2004), "Oil price shocks and the macroeconomy: What has been learned since 1996?", The Energy Journal 25(2), 1-32.

Kao, C. (1999), "Spurious regression and residual-based tests for cointegration in panel data", Journal of Econometrics 90, 1-44.

Keane, M.P. and E.S. Prasad (1996), "The employment and wage effects of oil price changes: A sectoral analysis", Review of Economics and Statistics 78, 389-400.

Kydland, F.E. and E.C. Prescott (1990), "Business cycles: Real facts and a monetary myth", Federal Reserve Bank of Minneapolis Quarterly Review, 3-18.

Lardic, S. and V. Mignon (2006), "Oil prices and economic activity: An asymmetric cointegration approach”, Energy Economics 34, 3910-3915.

LeBlanc, M. and M.D. Chinn (2004), "Do high oil prices presage inflation? The evidence from G5 countries", Business Economics 34, 38-48.

Lee, K., Ni, S. and R.A. Ratti (1995), "Oil shocks and the macroeconomy: The role of price variability”, Energy Journal 16(4), 39-56.

Levin, A. and C.F. Lin (1992), "Unit root tests in panel data: Asymptotic and finite sample properties", Discussion Paper 56, Department of Economics, University of California at San Diego.

Levin, A. and C.F. Lin (1993), "Unit root tests in panel data: new results", Discussion Paper 92-93, Department of Economics, University of California at San Diego.

Loungani, P. (1986), "Oil Price Shocks and the Dispersion Hypothesis", Review of Economics and Statistics 58, 536-539.

Maddala, G. and S. Wu (1999), "A comparative study of unit root tests and a new simple test", Oxford Bulletin of Economics and Statistics, 61, 631-652.

Mork, K.A. (1989), "Oil and the macroeconomy when prices goes up and down: An extension of Hamilton's results", Journal of Political Economy 97(3), 740-744.

Mork, K.A., Olsen, Ø. and H.T. Mysen (1994), "Macroeconomic responses to oil price increases and decreases in seven OECD countries", The Energy Journal 15(4), 19-35.

Papapetrou, E. (2001), "Oil price shocks, stock market, economic activity and employment in Greece", Energy Economics, 23(5), 511-532. 
On the influence of oil prices on economic activity and other macroeconomic and financial

variables

Pedroni, P. (1999), "Critical values for cointegration tests in heterogeneous panels with multiple regressors", Oxford Bulletin of Economics and Statistics, S1, 61, 653-670.

Pedroni, P. (2004), "Panel cointegration. Asymptotic and finite sample properties of pooled time series tests with an application to the PPP hypothesis", Econometric Theory 20, $597-625$.

Pierce, J.L. and J.J. Enzler (1974), "The effects of external inflationary shocks", Brookings Papers on Economic Activity 1, 13-61.

Rasche, R.H. and J.A. Tatom (1977a), "The effects of the new energy regime on economic capacity, production and prices", Federal Reserve Bank of St. Louis Review 59(4), 212.

Rasche, R.H. and J.A. Tatom (1977b), "Energy resources and potential GNP", Federal Reserve Bank of St. Louis, June, 10-24.

Rasche, R.H. and J.A. Tatom (1977c), "Potential output and its growth rate. The dominance of higher energy costs in the 1970's", Proceedings of the second annual economic policy conference of the Federal Reserve Bank of St. Louis, December.

Rasche, R.H. and J.A. Tatom (1981), "Energy price shocks, aggregate supply and monetary policy: The theory and the international evidence", in Brunner and Metzler (ed.), Supply shocks, incentives and national wealth, Carnegie-Rochester Conference Series on Public Policy 14, 9-93.

Sadorsky, P. (1999), "Oil price shocks and stock market activity", Energy Economics 21, $449-469$.

Tobin, J. (1980), "Stabilization policy ten years after", Brookings Papers on Economic Activity 1, 19-71. 


\section{APPENDIX}

Table A1. Panel unit root tests, OPEC.

\begin{tabular}{ccccc}
\hline \hline Variable & LL & Breitung & IPS & MW \\
\hline GDP & \multicolumn{2}{c}{ Variables in logarithms } & & \\
CPI & $-0.71(0.24)$ & $0.56(0.71)$ & $0.47(0.68)$ & $24.39(0.44)$ \\
Consumption & $-4.22(0)$ & $0.19(0.58)$ & $-0.42(0.33)$ & $32.24(0.12)$ \\
Share prices & $-0.27(0.39)$ & $1.93(0.97)$ & $-1.06(0.14)$ & $8.46(0.99)$ \\
Unemployment rate & $0.17(0.57)$ & $2.45(0.99)$ & $1.49(0.93)$ & $8.10(0.42)$ \\
& $0.39(0.65)$ & $1.13(0.87)$ & $1.12(0.86)$ & $5.83(0.44)$ \\
GDP & Variables in log first differences & & \\
CPI & $-11.59(0)$ & $-9.66(0)$ & $-11.82(0)$ & $177.7(0)$ \\
Consumption & $-4.69(0)$ & $-2.78(0)$ & $-5.79(0)$ & $83.22(0)$ \\
Share prices & $-6.77(0)$ & $-4.02(0)$ & $-9.90(0)$ & $155.26(0)$ \\
Unemployment rate & $-5.86(0)$ & $-4.13(0)$ & $-4.69(0)$ & $42.09(0)$ \\
\hline \hline
\end{tabular}

p-values are given in parentheses. LL: Levin and Lin; IPS: Im, Pesaran and Shin; MW: Maddala and Wu.

Table A2. Panel unit root tests, other oil-exporting countries.

\begin{tabular}{ccccc}
\hline \hline Variable & LL & Breitung & IPS & MW \\
\hline GDP & Variables in logarithms & & \\
CPI & $1.17(0.88)$ & $1.64(0.95)$ & $1.63(0.95)$ & $13.86(0.90)$ \\
Consumption & $0.11(0.54)$ & $1.91(0.97)$ & $1.59(0.94)$ & $12.62(0.94)$ \\
Share prices & $6.63(0.99)$ & $2.68(0.99)$ & $4.40(0.99)$ & $20.62(0.54)$ \\
Unemployment rate & $-0.66(0.25)$ & $0.81(0.79)$ & $0.86(0.80)$ & $11.26(0.79)$ \\
& $-0.57(0.28)$ & $0.23(0.59)$ & $-0.15(0.44)$ & $16.91(0.53)$ \\
GDP & Variables in log first differences & & \\
CPI & $-5.98(0)$ & $-2.57(0)$ & $-9.21(0)$ & $155.29(0)$ \\
Consumption & $-1.39(0.08)$ & $-2.10(0.01)$ & $-3.76(0)$ & $68.47(0)$ \\
Share prices & $-7.43(0)$ & $-3.24(0)$ & $-8.09(0)$ & $164.06(0)$ \\
Unemployment rate & $-12.55(0)$ & $-7.88(0)$ & $-11.43(0)$ & $148.03(0)$ \\
\hline \hline
\end{tabular}

p-values are given in parentheses. LL: Levin and Lin; IPS: Im, Pesaran and Shin; MW: Maddala and $\mathrm{Wu}$. 
On the influence of oil prices on economic activity and other macroeconomic and financial variables

Table A3. Panel unit root tests, oil-importing countries.

\begin{tabular}{ccccc}
\hline \hline Variable & LL & Breitung & IPS & MW \\
\hline GDP & Variables in logarithms & & \\
CPI & $-4.33(0)$ & $-1.16(0.12)$ & $-0.27(0.39)$ & $35.94(0.21)$ \\
Consumption & $-0.18(0.42)$ & $2.23(0.98)$ & $2.49(0.99)$ & $14.20(0.99)$ \\
Share prices & $-4.13(0)$ & $1.87(0.97)$ & $-0.59(0.27)$ & $37.13(0.17)$ \\
Unemployment rate & $1.92(0.97)$ & $-1.24(0.11)$ & $4.32(0.99)$ & $8.87(0.99)$ \\
& $-1.02(0.15)$ & $0.24(0.59)$ & $-1.16(0.12)$ & $36.26(0.14)$ \\
GDP & Variables in log first differences & & \\
CPI & $-13.01(0)$ & $-4.33(0)$ & $-13.89(0)$ & $233.76(0)$ \\
Consumption & $-2.36(0)$ & $-3.58(0)$ & $-3.49(0)$ & $62.92(0)$ \\
Share prices & $-9.28(0)$ & $-4.61(0)$ & $-10.96(0)$ & $187.49(0)$ \\
Unemployment rate & $-15.47(0)$ & $-13.67(0)$ & $-12.28(0)$ & $273.55(0)$ \\
\hline \hline
\end{tabular}

p-values are given in parentheses. LL: Levin and Lin; IPS: Im, Pesaran and Shin; MW: Maddala and $\mathrm{Wu}$. 
Table A4. Granger causality tests, OPEC.

\begin{tabular}{|c|c|c|c|c|c|c|c|c|c|c|}
\hline & $\begin{array}{c}\text { GDP } \\
\rightarrow \text { OIL }\end{array}$ & $\begin{array}{c}\text { OIL } \\
\rightarrow \text { GDP } \\
\end{array}$ & $\begin{array}{l}\text { CONS } \\
\rightarrow \mathrm{OIL}\end{array}$ & $\begin{array}{c}\text { OIL } \\
\rightarrow \text { CONS } \\
\end{array}$ & $\begin{array}{c}\text { CPI } \\
\rightarrow \text { OIL } \\
\end{array}$ & $\begin{array}{c}\text { OIL } \\
\rightarrow \text { CPI }\end{array}$ & $\begin{array}{c}\mathrm{UN} \\
\rightarrow \mathrm{OIL} \\
\end{array}$ & $\begin{array}{c}\mathrm{OIL} \\
\rightarrow \mathrm{UN}\end{array}$ & $\begin{array}{l}\text { SHAR } \\
\rightarrow \mathrm{OIL}\end{array}$ & $\begin{array}{c}\text { OIL } \\
\rightarrow \text { SHAR } \\
\end{array}$ \\
\hline Algeria & 0.61 & 0.19 & 0.70 & 2.86 & 5.01 & 2.29 & \# & \# & & \\
\hline Angola & 0.60 & 1.12 & & & 5.14 & 2.13 & & & & \\
\hline Indonesia & 2.10 & 1.94 & 5.86 & 4.45 & 0.46 & 0.19 & 5.34 & 0.41 & \# & \# \\
\hline Iran & 5.94 & 6.98 & 5.34 & $8.05^{*}$ & 2.53 & 1.68 & & & \# & \# \\
\hline Iraq & 1.08 & $15.77 * * *$ & 3.94 & 6.45 & 2.12 & $7.63 *$ & & & & \\
\hline Kuwait & 2.52 & $10.53 * *$ & 1.33 & 6.69 & 3.75 & 2.72 & \# & \# & & \\
\hline Libya & 2.49 & 0.95 & 3.72 & $8.28 *$ & $13.46 * * *$ & $10.04 * *$ & & & & \\
\hline Nigeria & 3.89 & 1.24 & 5.36 & 2.51 & 1.49 & 5.38 & & & & \\
\hline $\begin{array}{l}\text { Qatar } \\
\text { Saudi }\end{array}$ & $9.10 *$ & 6.41 & 4.83 & 4.68 & 1.70 & 2.01 & & & & \\
\hline $\begin{array}{c}\text { Arabia } \\
\text { United Arab }\end{array}$ & $10.65 * *$ & 5.41 & 3.54 & 5.87 & 6.04 & $8.92 *$ & & & 1.01 & 1.20 \\
\hline Emirates & 1.61 & 4.58 & 2.12 & 5.37 & 1.25 & $25.47 * * *$ & & & & \\
\hline Venezuela & 1.53 & 2.05 & 2.93 & $18.10 * * *$ & 1.57 & 5.38 & 3.37 & $11.22 * *$ & 3.61 & 0.82 \\
\hline
\end{tabular}


On the influence of oil prices on economic activity and other macroeconomic and financial variables

Table A5. Granger causality tests, oil-exporting countries.

\begin{tabular}{ccccccccccc}
\hline \hline & $\begin{array}{c}\text { GDP } \\
\rightarrow \text { OIL }\end{array}$ & $\begin{array}{c}\text { OIL } \\
\rightarrow \text { GDP }\end{array}$ & $\begin{array}{c}\text { CONS } \\
\rightarrow \text { OIL }\end{array}$ & $\begin{array}{c}\text { OIL } \\
\rightarrow \text { CONS }\end{array}$ & $\begin{array}{c}\text { CPI } \\
\rightarrow \text { OIL }\end{array}$ & $\begin{array}{c}\text { OIL } \\
\rightarrow \text { CPI }\end{array}$ & $\begin{array}{c}\text { UN } \\
\rightarrow \text { OIL }\end{array}$ & $\begin{array}{c}\text { OIL } \\
\rightarrow \text { UN }\end{array}$ & $\begin{array}{c}\text { SHAR } \\
\rightarrow \text { OIL }\end{array}$ & $\begin{array}{c}\text { OIL } \\
\rightarrow \text { SHAR }\end{array}$ \\
\hline Brazil & 6.64 & 1.21 & 3.31 & 0.68 & 5.00 & 1.09 & 1.32 & 2.29 & 2.16 & 2.03 \\
Canada & 2.55 & 6.65 & 3.77 & 3.49 & 3.98 & 3.76 & 1.85 & $11.46^{* *}$ & 1.49 & $9.12^{*}$ \\
Kazakhstan & 6.61 & 1.69 & 5.09 & 2.84 & 3.46 & 1.20 & $\#$ & $\#$ & & \\
Malaysia & 5.36 & 0.86 & 2.48 & 2.23 & 5.13 & 1.89 & 6.09 & 1.97 & 1.05 & $7.91^{*}$ \\
Mexico & 1.07 & 2.72 & 1.51 & 4.02 & 4.20 & $11.61 * *$ & $\#$ & $\#$ & 4.21 & $18.34^{* * *}$ \\
Oman & 6.99 & 1.31 & 0.85 & 1.76 & 0.79 & 0.69 & & & & \\
Norway & 2.15 & 3.45 & 5.22 & 2.39 & 0.37 & 6.04 & 0.24 & 0.73 & 5.42 & $18.85^{* * *}$ \\
Russia & 2.38 & 4.71 & 5.72 & 0.26 & 2.51 & 4.00 & $\#$ & $\#$ & & \\
UK & $9.79 * *$ & 6.12 & $9.01 *$ & $9.27 *$ & 0.37 & $20.31 * * *$ & 3.70 & $7.89 *$ & 5.69 & $17.11^{* * *}$ \\
\hline \hline
\end{tabular}

$*$ (resp. **,***): rejection of the null hypothesis of no causality at the $10 \%$ (resp. $5 \%, 1 \%$ ) significance level. \#: Not enough data to perform the test 
Table A6. Granger causality tests, oil-importing countries.

\begin{tabular}{|c|c|c|c|c|c|c|c|c|c|c|}
\hline & $\begin{array}{c}\text { GDP } \\
\rightarrow \text { OIL }\end{array}$ & $\begin{array}{c}\text { OIL } \\
\rightarrow \text { GDP }\end{array}$ & $\begin{array}{l}\mathrm{CONS} \\
\rightarrow \mathrm{OIL}\end{array}$ & $\begin{array}{c}\text { OIL } \\
\rightarrow \text { CONS } \\
\end{array}$ & $\begin{array}{c}\text { CPI } \\
\rightarrow \mathrm{OIL} \\
\end{array}$ & $\begin{array}{c}\mathrm{OIL} \\
\rightarrow \mathrm{CPI}\end{array}$ & $\begin{array}{c}\mathrm{UN} \\
\rightarrow \mathrm{OIL} \\
\end{array}$ & $\begin{array}{c}\text { OIL } \\
\rightarrow \mathrm{UN}\end{array}$ & $\begin{array}{l}\text { SHAR } \\
\rightarrow \mathrm{OIL} \\
\end{array}$ & $\begin{aligned} & \text { OIL } \\
& \rightarrow \text { SHAR } \\
&\end{aligned}$ \\
\hline Austria & 3.94 & 6.84 & 1.92 & 2.95 & 0.92 & $7.96^{*}$ & 5.99 & 5.14 & 1.49 & 3.39 \\
\hline Belgium & 2.09 & $9.42 *$ & $7.89^{*}$ & $9.42 *$ & 1.23 & 3.81 & 1.68 & 3.52 & 2.07 & $11.06^{* *}$ \\
\hline China & 1.57 & $11.26 * *$ & 7.14 & 1.77 & 2.96 & 5.13 & $9.16^{*}$ & 6.15 & \# & \# \\
\hline Finland & 6.38 & 1.66 & 6.66 & 2.79 & 0.46 & 5.69 & 4.69 & 4.90 & 3.00 & 6.42 \\
\hline France & 3.93 & $7.89 *$ & 6.51 & 2.94 & 1.71 & 1.45 & 1.81 & $7.91 * *$ & 3.16 & $10.59 * *$ \\
\hline Germany & 1.19 & 4.10 & 2.32 & 2.88 & 1.26 & 1.38 & 0.47 & 3.79 & 2.24 & 6.40 \\
\hline Greece & 7.63 & 4.73 & 5.73 & 1.76 & 6.25 & 1.44 & $15.82 * * *$ & 2.99 & \# & \# \\
\hline India & 2.98 & 3.69 & 3.34 & 5.77 & $8.50^{*}$ & 4.14 & & & 2.91 & 0.62 \\
\hline Ireland & 2.41 & 4.55 & 3.51 & $8.19^{*}$ & 0.78 & 5.31 & 3.07 & 2.04 & 1.23 & 4.52 \\
\hline Italy & 1.30 & 7.72 & 0.90 & 3.63 & 2.79 & 4.29 & 5.71 & 7.29 & 2.01 & 5.83 \\
\hline Luxembourg & 5.56 & $9.58 * *$ & 4.82 & 3.56 & 1.17 & 3.96 & 0.47 & $13.43 * * *$ & 0.87 & 1.89 \\
\hline Netherlands & 2.25 & 6.93 & 6.16 & 1.30 & 1.28 & $7.81 *$ & 5.12 & 6.74 & 1.60 & $8.93 *$ \\
\hline Portugal & 2.79 & 3.95 & 3.37 & 3.43 & 2.79 & 3.43 & 0.40 & 1.28 & 2.21 & 1.32 \\
\hline Spain & 5.75 & $9.18^{*}$ & 3.29 & $10.81 * *$ & 4.96 & 5.50 & $8.48 *$ & 6.14 & 1.06 & $9.67 * *$ \\
\hline US & 4.03 & $8.46^{*}$ & 2.56 & 3.11 & 5.79 & 3.21 & $8.35^{*}$ & $14.69 * * *$ & 2.67 & $9.40 *$ \\
\hline
\end{tabular}

$*$ (resp. **, ***): rejection of the null hypothesis of no causality at the $10 \%$ (resp. $5 \%, 1 \%$ ) significance level. \#: Not enough data to perform the test 
On the influence of oil prices on economic activity and other macroeconomic and financial variables

Table A7. Cyclical correlations of oil prices with GDP. $\rho\left(\mathrm{x}_{\mathrm{t}}, \mathrm{y}_{\mathrm{t}+\mathrm{i}}\right), \mathrm{j}=-5,-4,-3,-2,-1,0,1,2,3,4,5$

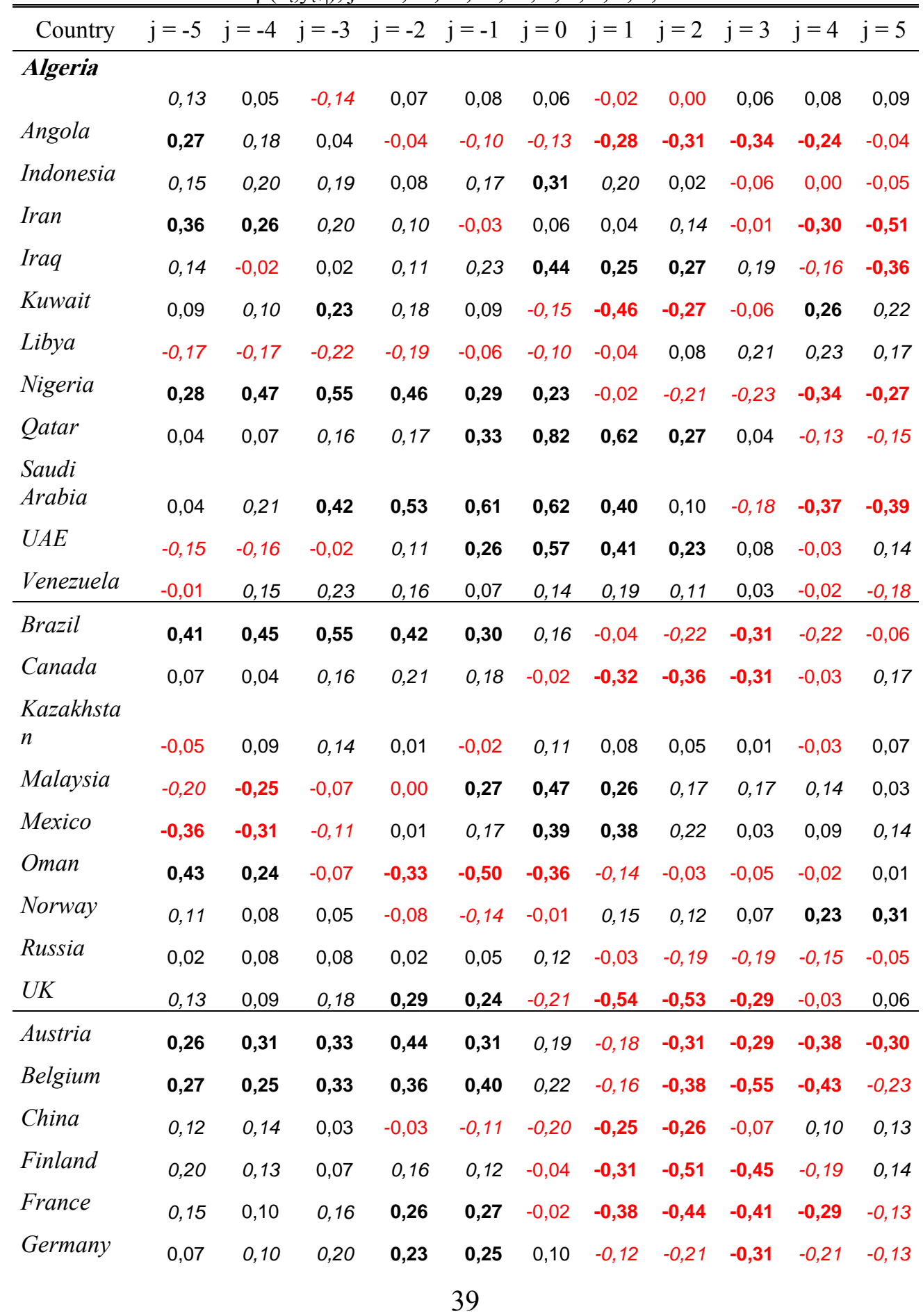


CEPII, Working Paper $N^{\circ} 2008$ - 05

\begin{tabular}{lccccccccccc}
\hline \multicolumn{1}{c}{ Country } & $\mathrm{j}=-5$ & $\mathrm{j}=-4$ & $\mathrm{j}=-3$ & $\mathrm{j}=-2$ & $\mathrm{j}=-1$ & $\mathrm{j}=0$ & $\mathrm{j}=1$ & $\mathrm{j}=2$ & $\mathrm{j}=3$ & $\mathrm{j}=4$ & $\mathrm{j}=5$ \\
\hline Greece & 0,05 & $\mathbf{0 , 2 9}$ & $\mathbf{0 , 3 9}$ & $\mathbf{0 , 4 1}$ & $\mathbf{0 , 3 2}$ & $-0,14$ & $-0,11$ & $-0,18$ & $-0,25$ & $-0,03$ & 0,02 \\
India & 0,15 & $\mathbf{0 , 2 4}$ & $-0,04$ & $-0,09$ & $-0,13$ & $-0,23$ & $-0,04$ & $-0,08$ & 0,07 & 0,12 & $-0,16$ \\
Ireland & 0,15 & 0,07 & 0,08 & 0,22 & 0,21 & 0,18 & 0,09 & $-0,09$ & $-0,04$ & $-0,03$ & 0,05 \\
Italy & $\mathbf{0 , 2 7}$ & 0,11 & 0,07 & 0,05 & 0,19 & 0,12 & $-0,23$ & $-0,29$ & $-0,38$ & $-0,22$ & 0,08 \\
Luxembou & & & & & & & & & & & \\
rg & $\mathbf{0 , 2 7}$ & 0,16 & $\mathbf{0 , 2 6}$ & $\mathbf{0 , 3 4}$ & $\mathbf{0 , 3 5}$ & 0,04 & $-0,32$ & $-0,47$ & $-0,49$ & $-0,36$ & $-0,33$ \\
Netherland & & & & & & & & & & & \\
S & $\mathbf{0 , 3 2}$ & $\mathbf{0 , 2 8}$ & 0,20 & 0,08 & 0,08 & $-0,03$ & $-0,25$ & $-\mathbf{0 , 3 3}$ & $-0,41$ & $-0,26$ & $-0,14$ \\
Portugal & $-0,07$ & 0,07 & $\mathbf{0 , 2 6}$ & $\mathbf{0 , 3 9}$ & $\mathbf{0 , 3 7}$ & 0,07 & $-0,23$ & $-0,31$ & $-0,40$ & $-0,39$ & $-0,21$ \\
Spain & $\mathbf{0 , 2 6}$ & 0,17 & $\mathbf{0 , 2 4}$ & $\mathbf{0 , 3 7}$ & $\mathbf{0 , 3 2}$ & 0,12 & $-0,17$ & $-0,37$ & $-0,48$ & $-0,50$ & $-\mathbf{0 , 4 4}$ \\
US & $-0,13$ & $-0,15$ & 0,02 & 0,12 & 0,12 & $-0,18$ & $-0,41$ & $-0,26$ & $-0,08$ & $\mathbf{0 , 2 3}$ & $\mathbf{0 , 2 7}$ \\
\hline \hline
\end{tabular}

Note: $\mathrm{x}_{\mathrm{t}}=$ oil prices, $\mathrm{y}_{\mathrm{t}}=$ GDP. 
On the influence of oil prices on economic activity and other macroeconomic and financial variables

Table A8. Cyclical correlations of oil prices with share prices.

$\rho\left(\mathrm{x}_{\mathrm{t}}, \mathrm{y}_{\mathrm{t}+\mathrm{i}}\right), \mathrm{j}=-5,-4,-3,-2,-1,0,1,2,3,4,5$

\begin{tabular}{|c|c|c|c|c|c|c|c|c|c|c|c|}
\hline Country & $j=-5$ & $j=-4$ & $j=-3$ & $j=-2$ & $\mathrm{j}=-1$ & $j=0$ & $\mathrm{j}=1$ & $\mathrm{j}=2$ & $\mathrm{j}=3$ & $\mathrm{j}=4$ & $j=5$ \\
\hline \multicolumn{12}{|l|}{ Algeria } \\
\hline \multicolumn{12}{|l|}{ Angola } \\
\hline Indonesia & 0,01 & 0,14 & 0,04 & $-0,27$ & 0,17 & 0,58 & $-0,11$ & $-0,11$ & 0,27 & 0,17 & $-0,13$ \\
\hline Iran & 0,24 & 0,54 & $-0,05$ & $-0,55$ & 0,02 & 0,35 & 0,13 & $-0,17$ & 0,05 & 0,14 & 0,03 \\
\hline \multicolumn{12}{|l|}{ Iraq } \\
\hline \multicolumn{12}{|l|}{ Kuwait } \\
\hline \multicolumn{12}{|l|}{ Libya } \\
\hline \multicolumn{12}{|l|}{ Nigeria } \\
\hline \multicolumn{12}{|l|}{ Qatar } \\
\hline \multicolumn{12}{|l|}{ Saudi } \\
\hline \multicolumn{12}{|l|}{$U A E$} \\
\hline Venezuela & 0,28 & 0,35 & 0,36 & 0,06 & $-0,07$ & 0,01 & $-0,02$ & $-0,09$ & $-0,11$ & $-0,13$ & $-0,22$ \\
\hline Brazil & $-0,11$ & $-0,19$ & $-0,11$ & 0,00 & 0,11 & 0,24 & 0,27 & 0,17 & 0,14 & 0,15 & $-0,12$ \\
\hline Canada & $-0,23$ & $-0,16$ & $-0,17$ & $-0,10$ & $-0,09$ & $-0,05$ & $-0,17$ & $-0,28$ & $-0,16$ & 0,36 & 0,44 \\
\hline \multicolumn{12}{|l|}{$\begin{array}{l}\text { Kazakhsta } \\
n\end{array}$} \\
\hline Malaysia & $-0,30$ & $-0,17$ & $-0,06$ & $-0,05$ & 0,26 & 0,62 & 0,14 & $-0,03$ & 0,10 & 0,04 & $-0,20$ \\
\hline Mexico & $-0,13$ & 0,37 & 0,43 & 0,26 & 0,06 & $-0,01$ & $-0,45$ & $-0,22$ & $-0,27$ & $-0,19$ & $-0,11$ \\
\hline \multicolumn{12}{|l|}{ Oman } \\
\hline Norway & 0,26 & 0,11 & 0,01 & $-0,15$ & $-0,10$ & $-0,01$ & $-0,28$ & $-0,40$ & $-0,53$ & $-0,17$ & 0,14 \\
\hline \multicolumn{12}{|l|}{ Russia } \\
\hline$U K$ & $-0,07$ & $-0,18$ & 0,05 & 0,02 & $-0,17$ & $-0,39$ & $-0,52$ & $-0,09$ & $-0,01$ & 0,20 & 0,27 \\
\hline Austria & 0,27 & 0,26 & 0,19 & 0,18 & 0,06 & 0,08 & $-0,07$ & $-0,25$ & $-0,41$ & $-0,34$ & $-0,20$ \\
\hline Belgium & 0,19 & 0,11 & 0,12 & 0,06 & 0,02 & $-0,03$ & $-0,45$ & $-0,28$ & $-0,30$ & $-0,06$ & 0,12 \\
\hline China & $-0,21$ & $-0,25$ & 0,28 & 0,32 & $-0,26$ & $-0,45$ & 0,20 & 0,00 & $-0,38$ & $-0,08$ & 0,13 \\
\hline Finland & 0,19 & 0,08 & 0,06 & 0,09 & 0,07 & $-0,16$ & $-0,44$ & $-0,51$ & $-0,28$ & $-0,02$ & 0,03 \\
\hline France & 0,15 & 0,21 & 0,08 & $-0,03$ & $-0,06$ & $-0,22$ & $-0,29$ & $-0,39$ & $-0,40$ & 0,00 & 0,12 \\
\hline Germany & 0,19 & 0,14 & 0,03 & $-0,12$ & $-0,16$ & $-0,29$ & $-0,24$ & $-0,07$ & $-0,15$ & 0,04 & 0,14 \\
\hline
\end{tabular}




\begin{tabular}{lccccccccccc}
\hline \multicolumn{1}{c}{ Country } & $\mathrm{j}=-5$ & $\mathrm{j}=-4$ & $\mathrm{j}=-3$ & $\mathrm{j}=-2$ & $\mathrm{j}=-1$ & $\mathrm{j}=0$ & $\mathrm{j}=1$ & $\mathrm{j}=2$ & $\mathrm{j}=3$ & $\mathrm{j}=4$ & $\mathrm{j}=5$ \\
\hline Greece & 0,12 & 0,02 & $-0,22$ & $-0,11$ & 0,00 & 0,23 & $-0,05$ & $-0,32$ & $-0,12$ & 0,14 & $-0,12$ \\
India & 0,05 & $-0,02$ & $-0,07$ & $-0,10$ & $-0,05$ & 0,03 & $-0,04$ & 0,05 & 0,07 & 0,02 & $-0,09$ \\
Ireland & $-0,05$ & 0,01 & 0,06 & 0,09 & $-0,12$ & $-0,41$ & $-0,34$ & $-0,22$ & 0,07 & $\mathbf{0 , 3 4}$ & $\mathbf{0 , 3 3}$ \\
Italy & 0,00 & $-0,07$ & $-0,18$ & $-0,21$ & $-0,20$ & $-0,27$ & $-0,25$ & $-0,25$ & $-0,29$ & $-0,03$ & $\mathbf{0 , 2 4}$ \\
Luxembou & & & & & & & & & & & \\
rg & 0,09 & 0,10 & 0,05 & 0,08 & 0,06 & $-0,06$ & $-0,17$ & $-0,24$ & $-0,16$ & 0,21 & 0,23 \\
Netherland & & & & & & & & & & & \\
S & 0,20 & 0,11 & $-0,04$ & $-0,13$ & $-0,26$ & $-0,36$ & $-0,28$ & $-0,21$ & $-0,18$ & 0,12 & 0,13 \\
Portugal & 0,01 & $-0,09$ & 0,04 & 0,18 & $-0,06$ & $-0,25$ & $-0,25$ & $-0,25$ & $-0,15$ & 0,13 & 0,00 \\
Spain & $\mathbf{0 , 3 4}$ & $\mathbf{0 , 2 9}$ & $\mathbf{0 , 2 4}$ & 0,09 & $-0,09$ & $-0,32$ & $-0,43$ & $-0,48$ & $-0,54$ & $-0,37$ & $-0,21$ \\
US & $-0,10$ & 0,06 & 0,10 & $-0,07$ & $-0,21$ & $-0,31$ & $-0,25$ & $-0,09$ & $-0,19$ & $-0,05$ & $-0,03$ \\
\hline \hline
\end{tabular}

Note: $\mathrm{x}_{\mathrm{t}}=$ oil prices, $\mathrm{y}_{\mathrm{t}}=$ share prices.

Table A9. Cyclical correlations of oil prices with macroeconomic and financial variables in the US.

$\rho\left(\mathrm{x}_{\mathrm{t}}, \mathrm{y}_{\mathrm{t}+\mathrm{j}}\right), \mathrm{j}=-5,-4,-3,-2,-1,0,1,2,3,4,5$

\begin{tabular}{ccccccccccccc}
\hline \hline Variable, $\mathrm{y}_{\mathrm{t}}$ & $\mathrm{j}=-5$ & $\mathrm{j}=-4$ & $\mathrm{j}=-3$ & $\mathrm{j}=-2$ & $\mathrm{j}=-1$ & $\mathrm{j}=0$ & $\mathrm{j}=1$ & $\mathrm{j}=2$ & $\mathrm{j}=3$ & $\mathrm{j}=4$ & $\mathrm{j}=\mathbf{5}$ \\
\hline GDP & $-0,13$ & $-0,15$ & 0,02 & 0,12 & 0,12 & $-0,18$ & $-\mathbf{0 , 4 1}$ & $-\mathbf{0 , 2 6}$ & $-0,08$ & $\mathbf{0 , 2 3}$ & $\mathbf{0 , 2 7}$ \\
CPI & $-0,15$ & $-0,13$ & $-0,15$ & $-0,10$ & 0,15 & $\mathbf{0 , 5 4}$ & $\mathbf{0 , 5 8}$ & $\mathbf{0 , 3 6}$ & 0,18 & 0,12 & 0,19 \\
Consumption & 0,07 & 0,09 & 0,12 & 0,15 & $-0,02$ & $-0,39$ & $-0,52$ & $-0,34$ & $-0,11$ & 0,14 & 0,13 \\
Share prices & $-0,10$ & 0,06 & 0,10 & $-0,07$ & $-0,21$ & $-0,31$ & $-\mathbf{0 , 2 5}$ & $-0,09$ & $-0,19$ & $-0,05$ & $-0,03$ \\
$\begin{array}{c}\text { Unemployment } \\
\text { rate }\end{array}$ & & & & & & & & & & & \\
\hline \hline
\end{tabular}

Note: $\mathrm{x}_{\mathrm{t}}=$ oil prices. 
On the influence of oil prices on economic activity and other macroeconomic and financial variables

Table A10. Cyclical correlations of oil prices with macroeconomic and financial variables in Spain.

$\rho\left(x_{t}, y_{t+i}\right), j=-5,-4,-3,-2,-1,0,1,2,3,4,5$

\begin{tabular}{ccccccccccccc}
\hline \hline Variable, $\mathrm{y}_{\mathrm{t}}$ & $\mathrm{j}=-5$ & $\mathrm{j}=-4$ & $\mathrm{j}=-3$ & $\mathrm{j}=-2$ & $\mathrm{j}=-1$ & $\mathrm{j}=0$ & $\mathrm{j}=1$ & $\mathrm{j}=2$ & $\mathrm{j}=3$ & $\mathrm{j}=4$ & $\mathrm{j}=5$ \\
\hline GDP & $\mathbf{0 , 2 6}$ & 0,17 & $\mathbf{0 , 2 4}$ & $\mathbf{0 , 3 7}$ & $\mathbf{0 , 3 2}$ & 0,12 & $-0,17$ & $-0,37$ & $-0,48$ & $-0,50$ & $-0,44$ \\
CPI & $-\mathbf{0 , 4 8}$ & $-0,41$ & $-0,26$ & $-0,09$ & 0,10 & $\mathbf{0 , 3 1}$ & $\mathbf{0 , 4 6}$ & $\mathbf{0 , 5 7}$ & $\mathbf{0 , 6 3}$ & $\mathbf{0 , 5 2}$ & $\mathbf{0 , 3 4}$ \\
Consumption & 0,15 & 0,20 & $\mathbf{0 , 3 0}$ & $\mathbf{0 , 4 0}$ & $\mathbf{0 , 3 8}$ & $\mathbf{0 , 2 3}$ & $-0,04$ & $-0,23$ & $-\mathbf{0 , 4 4}$ & $-0,53$ & $-0,48$ \\
Share prices & $\mathbf{0 , 3 4}$ & $\mathbf{0 , 2 9}$ & $\mathbf{0 , 2 4}$ & 0,09 & $-0,09$ & $-0,32$ & $-0,43$ & $-0,48$ & $-0,54$ & $-0,37$ & $-0,21$ \\
Unemp. rate & $-0,05$ & $-0,18$ & $-0,17$ & $-0,24$ & $-0,32$ & $-0,32$ & $-0,06$ & $\mathbf{0 , 2 8}$ & $\mathbf{0 , 5 9}$ & $\mathbf{0 , 4 9}$ & $\mathbf{0 , 2 4}$ \\
\hline \hline
\end{tabular}

Note: $\mathrm{x}_{\mathrm{t}}=$ oil prices.

Table A11. Multivariate Granger-causality tests in the US, 1962-2005.

\begin{tabular}{l|cccccc}
\multicolumn{7}{c}{$H_{0}:$ X does not Granger-cause $Y$} \\
\hline \hline $\mathrm{X} \backslash \mathrm{Y}$ & GDP & UN & CONS & SHAR & FFR & OIL \\
\hline GDP & & 0.37 & 0.71 & 0.91 & 0.13 & 2.09 \\
UN & 1.85 & & 1.71 & 3.37 & 0.77 & 0.70 \\
CONS & 0.59 & 2.94 & & $5.82 *$ & 2.88 & 2.22 \\
SHAR & 3.18 & $7.83 * *$ & 1.09 & & 0.71 & 2.31 \\
FFR & $14.38^{* * *}$ & $18.97 * * *$ & $4.88^{*}$ & 2.62 & & 1.19 \\
OIL & $8.32 * *$ & $15.65 * * *$ & 2.93 & 3.42 & 3.19 & \\
\hline
\end{tabular}

$*$ (resp. $* *, * * *$ ): rejection of the null hypothesis of no causality at the $10 \%$ (resp. $5 \%, 1 \%$ ) significance level. 


\section{List of working papers released by CEPII ${ }^{16}$}

No

2008-02 Equilibrium Exchange Rates: a Guidebook for the Euro-Dollar Rate

2008-01 How Robust are Estimated Equilibrium Exchange Rates? A Panel BEER Approach

2007-24 Testing the Finance-Growth Link: Is there a Difference between Developed and Developing Countries?

2007-23 Labor Migration: Macoeconomic and Demographic outlook for Europe and Neighborhood Regions

2007-22 Economic Geography, Spatial Dependence and Income Inequality in China

2007-21 Does FDI in Manufacturing Cause FDI in Business Services? Evidence from French Firm-Level Data

2007-20 Bilateral Trade of Cultural Goods

2007-19 China and India in International Trade: from Laggards to Leaders?

2007-18 How Remote is the Offshoring Threat

2007-17 Costs and Benefits of Euro Membership: a Counterfactual Analysis

2007-16 Location Decisions and Minimum Wages

2007-15 MIRAGE, Updated Version of the Model for Trade

\section{Authors}

A. Bénassy-Quéré,

S. Béreau

\& V. Mignon

A. Bénassy-Quéré,

S. Béreau

\& V. Mignon

G. Dufrénot,

V. Mignon

\& A. Péguin-Feissolle

V. Borgy

\& X. Chojnicki

L. Hering

\& S. Poncet

B. Nefussi

\& C. Schwellnus

A.C. Disdier,

S.H.T. Tai,

L. Fontagné

\& T. Mayer

F. Lemoine \& D. Ünal-Kesenci

K. Head, T. Mayer \& J. Ries

E. Dubois, J. Héricourt \& V. Mignon

I. Méjean \& L. Patureau

Y. Decreux

\footnotetext{
${ }^{16}$ Working papers are circulated free of charge as far as stocks are available; thank you to send your request to CEPII, Sylvie Hurion, 9, rue Georges-Pitard, 75015 Paris, or by fax : (33) 0153685504 or by e-mail Hurion@cepii.fr. Also available on: \lwww.cepii.fr. Working papers with * are out of print. They can nevertheless be consulted and downloaded from this website.

${ }^{16}$ Les documents de travail sont diffusés gratuitement sur demande dans la mesure des stocks disponibles. Merci d'adresser votre demande au CEPII, Sylvie Hurion, 9, rue Georges-Pitard, 75015 Paris, ou par fax : (33) 015368 5504 ou par e-mail Hurion@cepii.fr. Egalement disponibles sur: \www.cepii.fr. Les documents de travail comportant * sont épuisés. Ils sont toutefois consultable sur le web CEPII.
} 
On the influence of oil prices on economic activity and other macroeconomic and financial variables

Policy Analysis Focus on Agriculture and Dynamics

\& H. Valin

2007-14 Mondialisation des services de la mesure à l'analyse

I. Bendisoun

\& D. Ünal-Kesenci

2007-13 How are wages set in Beijing?

J. De Sousa

$\&$ S. Poncet

2007-12 IMF Quotas at Year 2030

A. Bénassy-Quéré,

S. Béreau,

Y. Decreux, C. Gouel

$\&$ S. Poncet

2007-11 FDI and Credit Constraints: Firm Level Evidence in China

J. Héricourt

$\&$ S. Poncet

2007-10 Fiscal Policy in Real Time

J. Cimadomo

2007-09 Global Ageing and Macroeconomic Consequences of Demographic Uncertainty in a Multi-regional Model

2007-08 The Effect of Domestic Regulation on Services Trade Revisited

2007-07 The Location of Domestic and Foreign Production Affiliates by French Multinational Firms

Alho \& V. Borgy

C. Schwellnus

T. Mayer, I. Méjean \& B. Nefussi

2007-06 Specialisation across Varieties within Products and North-South Competition

L. Fontagné, G. Gaulier \& S. Zignago

2007-05 Trade Costs and the Home Market Effect

M. Crozet \& F. Trionfetti

2007-04 The Impact of Regulations on Agricultural Trade: Evidence from SPS and TBT Agreements

2007-03 International Comparisons of Living Standards by Equivalent Incomes

A.-C. Disdier,

L. Fontagné

\& M. Mimouni

M. Fleurbaey \&

G. Gaulier

2007-02 Does Risk Aversion Drive Financial Crises? Testing the Predictive Power of Empirical Indicators

2007-01 Asian Catch Up, World Growth and International M. Aglietta, V. Borgy, Capital Flows in the XXIst Century : A Prospective Analysis with the INGENUE 2 Model

J. Château, M. Juillard, J. Le

Cacheux, G. Le

Garrec \& V. Touzé 


\section{CEPII \\ DOCUMENTS DE TRAVAIL / WORKING PAPERS}

Si vous souhaitez recevoir des Documents de travail, merci de remplir le coupon-réponse ci-joint et de le retourner à :

Should you wish to receive copies of the CEPII's Working papers, just fill the reply card and return it to:

Sylvie HURION - Publications

CEPII - 9, rue Georges-Pitard - 75740 Paris - Fax : (33) 1.53.68.55.04

sylvie.hurion@cepii.fr

M./Mme / Mr./Mrs

Nom-Prénom / Name-First name

Titre / Title .

Service / Department

Organisme / Organisation

Adresse / Address.

Ville \& CP / City \& post code.

Pays / Country. Tél.

Your e-mail

Désire recevoir les Document de travail du CEPII ${ }^{\circ}$ :

Wish to receive the CEPII's Working Papers No:

Souhaite être placé sur la liste de diffusion permanente (pour les bibliothèques)

Wish to be placed on the standing mailing list (for Libraries). 